\title{
Effect of intercropping, phosphorus fertilization and rhizobium inoculation on the growth and nodulation of some leguminous and cereal forages
}

\author{
Awad O. Abusuwar ${ }^{1}$ and Eltahir A. Omer ${ }^{2}$ \\ ${ }^{1}$ Dept. of Arid land Agriculture, King A/Aziz University, Jeddah, Saudi Arabia \\ E-mail: Abusuwar@yahoo.com \\ ${ }^{2}$ Faculty of Natural Resources, University of Upper Nile, Malakal, Sudan \\ ABSTRACT
}

\begin{abstract}
A field experiment was carried out for two consecutive seasons (2005/2006 and 2006/2007) in the Demonstration Farm of the Faculty of Agriculture at Shambat, University of Khartoum, Sudan, to study the effect of intercropping, phosphorus application and Rhizobium inoculation on the performance of some leguminous and cereal forage crops. The treatments used were pure stand, a mixture of Clitoria, lablab and Sudan grass, phosphorus fertilizer and Rhizobium inoculation. They were laid out in a completely randomized block design with three replications. Growth attributes, number of nodules, weight of nodules and prussic acid ( $\mathrm{HCN}$ ) were measured. Results showed that stem thickness was significantly affected by intercropping and addition of phosphorus. Sole crops produced forage with thicker stems during the growth of the first crop, while intercropped plants treated with phosphorus developed thicker stems during the second cut (ratoon). The plant cover was significantly higher for Clitoria than the other species. Intercropping and addition of phosphorus increased plant height of Sudan grass. The leaf area of Clitoria was increased with the addition of phosphorus and intercropping in the first crop, but sole Clitoria scored higher leaf area during the second cut. Lablab leaf area was significantly increased with addition of phosphorus and intercropping in the two seasons. Intercropping of Sudan grass with lablab and Clitoria resulted in large leaf area of Sudan grass. Leaf to stem ratio of Clitoria was mainly increased with the addition of phosphorus. Intercropping lablab with Clitoria significantly increased lablab leaf to stem ratio. The two-combination intercropping of Sudan grass increased its leaf to stem ratio. Rhizobium inoculation, legume to legume intercropping and addition of phosphorus enhanced nodulation and increased the number and weight of nodules. Phosphorus significantly reduced the amount of HCN in the forage of Sudan grass.
\end{abstract}

Keywords: intercropping, bio-fertilization, grass-legume mixture, phosphorus fertilization

\section{INTRODUCTION}

Sustaining bio-diversity in nature is very crucial, simply because of human intervention through the process of isolating certain plants from their communities, which affects the natural distribution of plants in nature. Intercropping is the growing of two or more crops on the same land and at the same time. It is one of the methods used to return plant configuration to its natural diversity.

Bio-fertilization is the use of organic matter or microbiological inoculation to increase soil fertility. Rhizobium plays an important role in agriculture by inducing nitrogen fixing nodules on the roots of legumes. Nitrogen fixation is one of most important biological processes on earth (Graham, 2008) and Rhizobium inoculation of legumes is one of the success stories of world agriculture (Herridge, 2008).
The process of nitrogen fixation is much cost energetically. Addition of nitrogen through the process of nitrogen fixation is cheap to the farmer, without any hazards, avoiding the use of chemical fertilizer. Intercropping of non-legume and leguminous crops probably reduce competition for nitrogen . Lablab bean is a very excellent nitrogen fixer, it is used for human consumption, cover crop and for animal feeding. Clitoria combines well with Sudan grass and some other crops, beside its palatability and nutritional value for animal. The peculiarity of the family Fabaceae is the production of bacterial nodules. Roots of leguminous plant infected by bacteria of the genus Rhizobium form nodules that vary in number and size.

Sorghum sudanense a non-leguminous crop that needs large amounts of nitrogen from the soil. The presence of Clitoria and hyacinth bean in the 
intercropping system with Sudan grass will help the availability of nitrogen through the process of $\mathrm{N}$ fixation (nodules). The success of this process depends on the amount and activity of the bacteria in the soil.

Sudan grass like many other members of the family Poaceae, (Johnson grass and Sorghum) contains cynogenic glycoside, which produces prussic acid (poisonous substance to animals) (Abusuwar, 2005). Prussic acid (HCN) inhibits oxygen utilization by the cells in the animal body, cattle and sheep (ruminant) are more susceptible. The addition of phosphorus reduces the amount of this substance in the plant tissues, and increases the resistance to plant lodging. Phosphorus is the component of the genetic materials (DNA and RNA) and an essential element in all living cells.

Therefore, the main objective of this study was to explore the possibility of providing green forage from an intercropping system of leguminous and nonleguminous crops with high productivity and high nutritional value. The specific objectives were to: astudy the effect of phosphorus fertilization and Rhizobium inoculation on the growth and yield of cereal and leguminous forage crops, and b-evaluate mixed cropping versus monocropping systems.

\section{MATERIALS AND METHODS}

Experimental site description: The Demonstration Farm of the Faculty of Agriculture at Shambat (latitude $15^{\circ} 40^{\prime} \mathrm{N}$ and longitude $32^{\circ} 32^{\prime} \mathrm{E}$ and altitude $280 \mathrm{~m}$ above sea level) has a semi-desert climate with annual precipitation between 100 and $200 \mathrm{~mm}$. and a temperature ranges from $12^{\circ} \mathrm{C}$ to $42^{\circ} \mathrm{C}$. (Shambat Meteorological Station,2008).

\section{Land preparation:}

Four operations were carried out; ploughing, harrowing, leveling, and ridging $70 \mathrm{~cm}$ apart. The size of the plot was $3 \times 5 \mathrm{~m}$ with six ridges. The experimental plots were protected with a guard area planted with Sorghum.

Treatments

Treatments used were:

1- Sorghum sudanense (pure stand)

2- Clitoria ternatea (pure stand)

3- Lablab purpureus (pure stand)

4- Sorghum sudanense: Clitoria ternatea

5- Sorghum sudanense: Lablab purpureus

6- Sorghum sudanense: Lablab purpureus : Clitoria ternatea
7- Sorghum sudanense + Phosphorous

8- Clitoria ternatea + Phosphorous

9- Lablab purpureus + Phosphorous

10- Sorghum sudanense: Lablab purpureus : Clitoria ternatea + Phosphorous

11- Sorghum sudanense: Lablab purpureus : Clitoria ternatea + Phosphorous + Rhizobium

12- Clitoria ternatea + Rhizobium

13- Lablab purpureus + Rhizobium

14- Clitoria ternatea : Lablab purpureus

15- Clitoria ternatea: Lablab purpureus+ Phosphorous

16- Clitoria ternatea: Lablab purpureus+ Rhizobium

17- Clitoria ternatea: Lablab purpureus+ Phosphorous+ Rhizobium

18- Sorghum sudanense: Clitoria ternatea+ Phosphorous

19- Sorghum sudanense : Clitoria ternatea+ Rhizobium

20- Sorghum sudanense: Clitoria ternatea+ Rhizobium + Phosphorous

21- Clitoria ternatea + Rhizobium+ Phosphorous

22- Lablab purpureus + Rhizobium+ Phosphorous

23- Sorghum sudanense: Lablab purpureus : Clitoria ternatea+ Rhizobium

24- Sorghum sudanense : Lablab purpureus+ Phosphorous

25- Sorghum sudanense : Lablab purpureus+ Phosphorous+ Rhizobium

26- Sorghum sudanense : Lablab purpureus + Rhizobium

Treatments were replicated three times and the number of experimental plots were equal to 78 using a Randomized Complete Block Design.

Inoculation: The leguminous seeds were inoculated before planting with their Rhizobium strains in form of black powder, brought from the National Research Center and USDA3398 for Lablab and USDA3384 for Clitoria

Phosphorous addition: Phosphorous was added in the form of triple supper phosphate at a rate of $50 \mathrm{~kg}$ per hectare before planting.

Seed rate: For sorghum, Clitoria and lablab, seeding rates applied were, 10, 15, $20 \mathrm{~kg} /$ feddan, respectively. In case of mixture, the seed rate was half or third of that of the sole crop (half incase of two mixtures and third incase of three mixtures). 
Sowing date: The first and the second season experiments were planted at the first week of March 2005 and 2006. The first ratoons started after harvesting.

Method of planting: Seeds of legumes were drilled into the shoulders of the ridges, alternated with Sorghum seeds, row intercropping (1: 1)

Irrigation: The experiment was irrigated immediately after planting to avoid death of bacteria ( Rhizobium ) and weekly thereafter.

Weed control: The most common weeds were Buda (Striga hermonthica), Nageela (Cynadon dactylon) and Saeda (Cyprus rotundus). Weeding was carried out once after three weeks from planting. White fly was the most common insect infested lablab plants, but did not reach threshold level.

Parameters measured: Five tagged plants for each crop in the plot were taken at random from the middle rows to measure growth parameters.

Stem diameter: It was taken from the second internodes at the base of the plant after 15 days from planting and one month thereafter using a Vernia.

Leaf area: For sorghum plant, leaf number four from the top was used to determine the leaf area by leaf area meter. For leguminous plants, a fully grown compound leaf was chosen randomly to measure the leaf area, at one month interval.

Leaf-to-stem ratio: The weight of removed leaves of five randomly selected plants was divided by the weight of their stems at one month interval.

Number and weight of nodules: Three plants were uprooted for recording nodulation. Nodules were removed from roots of legumes, counted; fresh and dry weights were determined. This was done twice; six weeks from planting and at harvest.

Prussic acid: This parameter was taken at the time of harvest, for the main crop and the ratoon. Five Sorghum plants were taken randomly, milled using pressure machine; the extracted juice was collected, filtered and centrifuged. The Spectrophotometer was used to determine the absorption of juice at wave length $(\lambda)=293 \mathrm{~nm}$, glycoside concentration was calculated according to the formula described by British Pharmacopoeia (1980).

\section{$\mathrm{HCN}$ content $=$ glycoside concentration $x$ $1.03 \times 1000 / 10.5$}

Data analysis: Randomized Complete Block Design was used, in which the main 26 treatments were further fractionated to obtain 16,16 , and 12 treatments consisted of Clitoria, Lablab and Sorghum, respectively and each crop was statistically analyzed separately

\section{RESULTS \\ Stem diameter $(\mathbf{c m})$}

Clitoria ternatea: Clitoria thickness was significantly different with treatments in all readings except the first reading of the two seasons (Tables $1 a$ and $1 b$ ). Stem diameter increased with plant age. In the second readings it was significantly affected by treatments and sole Clitoria treated with $\mathrm{P}$ gave the thickest stems among the treatments of the second reading of the two seasons $(0.38 \mathrm{~cm}$ for the first season and $0.57 \mathrm{~cm}$ for the second season).

At time of harvest in the first season, Clitoria (CL) treated with phosphorus $(P)$ and Rhizobium ( $R$ ) resulted in thicker plants $(0.51 \mathrm{~cm})$, whereas $C L / P / R$ treatment gave the thickest stem in the second season $(0.78 \mathrm{~cm})$. Addition of $\mathrm{P}$ and $\mathrm{R}$ relatively increased plant thickness.

Ratoon plant was thicker than the first cut. First season ratoon gave plant with stem diameters ranged between 0.61 and $1 \mathrm{~cm}$, whereas second season ratoon ranged between 0.48 and $0.92 \mathrm{~cm}$.

Lablab purpureus: Stem diameter in the first and second reading of the first season did not respond significantly to the treatments, even though sole lablab developed thicker stem in the first reading and $\mathrm{CL} / \mathrm{P} / \mathrm{R}$ in the second reading.

Treatments in the first reading of the second season revealed significant difference for stem diameter (SD), in which LC/R treated plants were significantly thicker than non-treated plants $(1.38 \mathrm{~cm})$. Planting lablab with Sorghum and Clitoria gave relatively thinner stems. At the time of harvest of the first cut lablab grown alone and lablab treated with $\mathrm{P}$ and $\mathrm{R}$ yielded thicker stems (1and $0.95 \mathrm{~cm}$, respectively). Last reading of the second season showed that L/P/R treatment had the thicker stems $(1.37 \mathrm{~cm})$ and generally sole lablab obtained thicker stems. 
Agric. Biol. J. N. Am., 2011, 2(1): 109-124

Table 1.a. Effect of intercropping, phosphorus and inoculation on stem diameter (cm) of Clitoria, lablab and sorghum (2005)

\begin{tabular}{|c|c|c|c|c|c|c|c|c|c|c|c|c|}
\hline \multirow[b]{2}{*}{ Treatment } & \multicolumn{4}{|c|}{ Clitoria } & \multicolumn{4}{|c|}{ Lablab } & \multicolumn{4}{|c|}{ Sorghum } \\
\hline & $\begin{array}{c}1^{\text {st }} \\
\text { reading }\end{array}$ & $\begin{array}{c}2^{\text {nd }} \\
\text { reading }\end{array}$ & $\begin{array}{c}\text { At } 1^{\text {st }} \\
\text { harvest }\end{array}$ & $\begin{array}{c}\text { At }^{\text {nd }} \\
\text { harvest }\end{array}$ & $\begin{array}{c}1^{\text {st }} \\
\text { reading }\end{array}$ & $\begin{array}{c}2^{\text {nd }} \\
\text { reading }\end{array}$ & $\begin{array}{c}\text { At } 1^{\text {st }} \\
\text { harvest }\end{array}$ & $\begin{array}{c}\text { At } 2^{\text {nd }} \\
\text { harvest }\end{array}$ & $\begin{array}{c}1^{\text {st }} \\
\text { reading }\end{array}$ & $\begin{array}{c}2^{\text {nd }} \\
\text { reading }\end{array}$ & $\begin{array}{c}\text { At } 1^{\text {st }} \\
\text { harvest }\end{array}$ & $\begin{array}{c}\text { At } 2^{\text {nd }} \\
\text { harvest }\end{array}$ \\
\hline$L / P / R$ & & & & & $0.367 \mathrm{~s}$ & $0.68 a$ & $0.95 a$ & $1.31 \mathrm{ab}$ & & & & \\
\hline $\mathrm{SCL}$ & $0.16 a$ & $0.28 \mathrm{abc}$ & $0.42 a b$ & $1 a$ & $0.367 a$ & $0.55 a$ & 0.88 & $0.53 \mathrm{e}$ & $0.18 a$ & $0.54 \mathrm{abc}$ & $0.48 a$ & $0.57 \mathrm{bcde}$ \\
\hline $\mathrm{SC} / \mathrm{P} / \mathrm{R}$ & $0.17 a$ & $0.31 \mathrm{abc}$ & $0.493 a b$ & $0.69 \mathrm{def}$ & & & & & $0.16 a$ & $0.42 c$ & $0.47 a$ & $0.56 \mathrm{bcde}$ \\
\hline $\mathrm{SL}$ & & & & & $0.31 a$ & $0.65 a$ & $0.76 \mathrm{abcd}$ & $1 \mathrm{bcd}$ & $0.22 a$ & $0.5 a b c$ & $0.46 a$ & $0.69 \mathrm{bcd}$ \\
\hline SL /R & & & & & $0.367 a$ & $052 a$ & $0.64 \mathrm{~cd}$ & $1.32 \mathrm{ab}$ & $0.31 a$ & $0.42 \mathrm{c}$ & $0.38 a$ & $0.60 \mathrm{bcde}$ \\
\hline SL/P & & & & & 0.363 & $0.60 \mathrm{a}$ & $0.753 \mathrm{abcd}$ & $1.28 \mathrm{abc}$ & $0.20 \mathrm{a}$ & $0.53 \mathrm{abc}$ & $0.55 \mathrm{a}$ & $0.76 \mathrm{ab}$ \\
\hline SL/P/R & & & & & $0.357 a$ & $0.61 a$ & 072abcde & $0.93 \mathrm{bcde}$ & $0.21 a$ & $0.67 a$ & $0.55 a$ & $0.56 \mathrm{bcde}$ \\
\hline L & & & & & $0.39 a$ & $0.69 a$ & $1 a$ & $0.997 \mathrm{bcde}$ & & & & \\
\hline L/P & & & & & 0.38 & $0.69 \mathrm{a}$ & $0.71 \mathrm{bcd}$ & $1.5 \mathrm{a}$ & & & & \\
\hline$S$ & & & & & & & & & $0.27 a$ & $0.36 a b$ & $0.36 a$ & $0.71 \mathrm{bc}$ \\
\hline $\mathrm{SCL} / \mathrm{P} / \mathrm{R}$ & $0.010 \mathrm{a}$ & $0.27 \mathrm{abc}$ & 0.35 & 0.686 def & $0.57 a$ & $0.51 \mathrm{a}$ & $0.71 \mathrm{bcd}$ & $0.87 \mathrm{de}$ & $0.38 a$ & $0.48 \mathrm{abc}$ & $0.39 a$ & $0.55 \mathrm{bcde}$ \\
\hline$L / R$ & & & & & $0.33 a$ & $0.637 a$ & $0.62 \mathrm{~cd}$ & $1.46 a$ & & & & \\
\hline SCL/R & $0.20 \mathrm{a}$ & $0.31 \mathrm{abc}$ & $0.46 a b$ & $0.72 \mathrm{cdef}$ & $38 . a$ & $0.64 a$ & $0.83 \mathrm{abc}$ & $0.867 \mathrm{de}$ & $0.27 a$ & $0.65 a$ & $0.48 a$ & $0.51 \mathrm{cde}$ \\
\hline $\mathrm{SCL} / \mathrm{P}$ & $0.167 a$ & $0.7 \mathrm{abc}$ & $0.46 a b$ & $0.77 \mathrm{bcdef}$ & $0.38 a$ & $0.60 a$ & $0.75 a b c d e$ & $0.9 \mathrm{cde}$ & 0.25 & $0.5 a b c$ & $0.50 \mathrm{a}$ & $0.54 \mathrm{cde}$ \\
\hline $\mathrm{C} / \mathrm{P}$ & 0.203 & $0.8 a$ & $0.44 a b$ & $0.77 \mathrm{bcdef}$ & & & & & & & & \\
\hline $\mathrm{C} / \mathrm{P} / \mathrm{R}$ & $0.11 \mathrm{a}$ & $0.28 a b c$ & $0.51 \mathrm{a}$ & $0.87 \mathrm{abc}$ & & & & & & & & \\
\hline SC & $0.16 a$ & $0.28 a b c$ & $0.39 a b$ & $0.80 \mathrm{bcde}$ & & & & & $0.19 a$ & $0.54 a b c$ & $0.48 a$ & $0.49 \mathrm{de}$ \\
\hline $\mathrm{SC} / \mathrm{R}$ & $167 a$ & $0.37 a b$ & $0.39 a b$ & $0.64 \mathrm{ef}$ & & & & & $0.29 a$ & $0.38 c$ & $0.38 a$ & $0.47 \mathrm{e}$ \\
\hline $\mathrm{SC} / \mathrm{P}$ & $0.19 a$ & $0.29 \mathrm{abc}$ & $0.46 \mathrm{ab}$ & $0.61 \mathrm{f}$ & & & & & $0.25 a$ & $0.41 \mathrm{c}$ & $0.40 \mathrm{a}$ & $0.39 \mathrm{e}$ \\
\hline $\mathrm{S} / \mathrm{P}$ & & & & & & & & & $0.22 a$ & $0.43 \mathrm{bc}$ & $0.44 a$ & $0.91 \mathrm{a}$ \\
\hline$C$ & $0.18 a$ & $0.29 \mathrm{abc}$ & $0.47 \mathrm{ab}$ & $0.90 \mathrm{ab}$ & & & & & & & & \\
\hline $\mathrm{CL} / \mathrm{P}$ & $0.13 a$ & $0.26 \mathrm{bc}$ & $0.34 \mathrm{~b}$ & $0.85 \mathrm{abcd}$ & 033a & $0.72 a$ & $0.68 \mathrm{bcd}$ & $0.75 \mathrm{de}$ & & & & \\
\hline $\mathrm{CL}$ & $0.20 \mathrm{a}$ & $0.31 \mathrm{abc}$ & $0.49 a b$ & $0.77 \mathrm{bcdef}$ & $0.33 a$ & $0.633 a$ & $0.747 \mathrm{abcd}$ & $0.80 \mathrm{de}$ & & & & \\
\hline $\mathrm{C} / \mathrm{R}$ & 18.a & $0.30 \mathrm{abc}$ & $0.45 \mathrm{ab}$ & $0.70 \mathrm{cdef}$ & & & & & & & & \\
\hline $\mathrm{CL} / \mathrm{R}$ & $1.10 a$ & $.0 .26 \mathrm{bc}$ & $0.40 \mathrm{ab}$ & $0.75 \mathrm{bcdef}$ & $0.325 a$ & $0.75 a$ & $0.70 \mathrm{bcde}$ & $0.84 \mathrm{de}$ & & & & \\
\hline $\mathrm{CL} / \mathrm{P} / \mathrm{R}$ & $0.21 \mathrm{a}$ & $0.28 a b c$ & $0.42 a b$ & $0.90 \mathrm{ab}$ & $0.375 a$ & $0.77 a$ & 080abc & $0.79 \mathrm{de}$ & & & & \\
\hline SE \pm & 0.007 & 0.007 & 0.01 & 0.01 & 0.02 & 0.02 & 0.02 & 0.3 & 0.02 & 0.02 & 0.02 & 0.07 \\
\hline CV & 28.6 & 17.2 & 17.18 & 9.57 & 31.8 & 18.1 & 16.04 & 17.3 & 60.2 & 21 & 29.4 & 8.6 \\
\hline
\end{tabular}

Means with the same letter (s) within each column are not significantly different at 0.05 level using Duncan's Multiple Range Test.

Legend: $C$ = Clitoria, $L=$ lablab, $S=$ sorghum, $P$ = phosphors, $R=$ Rhizobium

Table 1.b. Effect of intercropping, phosphorus and inoculation on stem diameter (cm) of Clitoria, lablab and sorghum (2006) 
Agric. Biol. J. N. Am., 2011, 2(1): 109-124

\begin{tabular}{|c|c|c|c|c|c|c|c|c|c|c|c|c|}
\hline & $\begin{array}{l}1^{\text {st }} \\
\text { reading }\end{array}$ & $\begin{array}{l}2^{\text {nd }} \\
\text { reading }\end{array}$ & $\begin{array}{c}\text { At } 1^{\text {st }} \\
\text { harvest }\end{array}$ & $\begin{array}{c}\text { At } 2^{\text {nd }} \\
\text { harvest }\end{array}$ & $\begin{array}{l}1^{\text {st }} \\
\text { reading }\end{array}$ & $\begin{array}{l}2^{\text {nd }} \\
\text { reading }\end{array}$ & $\begin{array}{c}\text { At } 1^{\text {st }} \\
\text { harvest }\end{array}$ & $\begin{array}{c}\text { At } 2^{\text {nd }} \\
\text { harvest }\end{array}$ & $\begin{array}{l}1^{\text {st }} \\
\text { reading }\end{array}$ & $\begin{array}{l}2^{\text {nd }} \\
\text { reading }\end{array}$ & $\begin{array}{c}\text { At } 1^{\text {st }} \\
\text { harvest }\end{array}$ & $\begin{array}{c}\text { At } 2^{\text {nd }} \\
\text { harvest }\end{array}$ \\
\hline$L / P / R$ & & & & & $0.37 a b$ & $1.19 \mathrm{ab}$ & $1.37 a$ & 1.4bdce & & & & \\
\hline $\mathrm{SCL}$ & 0.18 & 0.43 & $0.34 \mathrm{ab}$ & $0.87 a b$ & $0.32 \mathrm{abc}$ & $0.84 \mathrm{bc}$ & $0.87 \mathrm{ab}$ & $0.75 \mathrm{ef}$ & $0.21 a$ & $0.55 a$ & $0.71 \mathrm{ab}$ & $0.77 \mathrm{defg}$ \\
\hline $\mathrm{SC} / \mathrm{P} / \mathrm{R}$ & $0.167 a$ & $0.39 \mathrm{~b}$ & $0.47 a b$ & $0.60 \mathrm{bcde}$ & & & & & $0.20 a$ & $0.68 a$ & $0.70 \mathrm{ab}$ & $0.57 \mathrm{defg}$ \\
\hline SL & & & & & $0.35 \mathrm{abc}$ & $0.81 \mathrm{bc}$ & $0.77 \mathrm{~b}$ & 0.897 def & $0.10 \mathrm{~b}$ & $0.53 a$ & $0.56 \mathrm{~b}$ & $0.74 \mathrm{cdef}$ \\
\hline $\mathrm{SL} / \mathrm{R}$ & & & & & $0.25 c$ & $0.87 \mathrm{bc}$ & $0.9 a b$ & $1.2 \mathrm{bdef}$ & $0.11 \mathrm{~b}$ & $0.61 a$ & 0.67 & $1.11 \mathrm{a}$ \\
\hline SL/P & & & & & $0.30 \mathrm{abc}$ & $0.92 \mathrm{bc}$ & $0.93 a b$ & $1.27 \mathrm{fbdef}$ & $0.14 a b$ & $0.52 a$ & $0.76 \mathrm{ab}$ & $1 \mathrm{abc}$ \\
\hline SL/P/R & & & & & $0.28 \mathrm{bc}$ & $0.83 \mathrm{bc}$ & 0.99ab & $1.57 \mathrm{bdc}$ & $0.14 a b$ & 0.68 & $0.78 \mathrm{ab}$ & $0.82 \mathrm{bcde}$ \\
\hline$L$ & & & & & $0.30 \mathrm{abc}$ & $0.93 b c$ & $1.012 \mathrm{ab}$ & & & & & \\
\hline $\mathrm{L} / \mathrm{P}$ & & & & & $0.28 b c$ & $0.987 \mathrm{abc}$ & $0.9 \mathrm{ab}$ & $1.77 \mathrm{abc}$ & & & & \\
\hline$S$ & & & & & & & & & $0.15 \mathrm{ab}$ & $0.57 a$ & $0.65 a b$ & $0.8 \mathrm{bcdef}$ \\
\hline SCL/P/R & $0.13 a$ & $0.5 b$ & $0.53 a b$ & $0.67 \mathrm{bcdef}$ & $0.26 \mathrm{c}$ & $0.86 \mathrm{bc}$ & $0.83 a b$ & 1.17bcdef & $0.167 a b$ & $0.66 a$ & $0.72 \mathrm{ab}$ & $0.51 \mathrm{fg}$ \\
\hline L/R & & & & & $0.26 c$ & $1.11 \mathrm{abc}$ & $0.92 \mathrm{ab}$ & $1.8 \mathrm{ab}$ & & & & \\
\hline $\mathrm{SCL} / \mathrm{R}$ & $0.14 a$ & $0.45 b$ & $0.44 a b$ & $0.92 a$ & 0.31 & $0.81 \mathrm{c}$ & $0.93 a b$ & $1.1 \mathrm{cdef}$ & $0.167 a b$ & $0.59 a$ & $0.78 \mathrm{ab}$ & 1.04ab \\
\hline $\mathrm{SCL} / \mathrm{P}$ & $0.2 a$ & $0.44 b$ & $0.42 a b$ & $\begin{array}{c}0.697 a b c d \\
e\end{array}$ & $0.28 \mathrm{bc}$ & $0.79 c$ & 0.81 & $0.83 \mathrm{ef}$ & $0.10 \mathrm{~b}$ & $0.53 a$ & $0.82 a$ & $0.62 \mathrm{defg}$ \\
\hline $\mathrm{C} / \mathrm{P}$ & $0.19 a$ & $0.49 b$ & $0.57 a$ & $0.58 \mathrm{def}$ & & & & & & & & \\
\hline $\mathrm{C} / \mathrm{P} / \mathrm{R}$ & $0.14 a$ & $0.40 \mathrm{~b}$ & $0.43 a$ & $0.71 \mathrm{abcdef}$ & & & & & & & & \\
\hline SC & $0.17 a$ & $0.43 b$ & $0.48 a b$ & $0.62 \mathrm{cdef}$ & & & & & $0.13 a b$ & $0.52 a$ & $0.61 \mathrm{ab}$ & 0.52 efg \\
\hline SC/R & $0.13 a$ & $0.44 b$ & $0.49 a b$ & $0.67 \mathrm{bcdef}$ & & & & & 0.13 & $0.63 a$ & $0.72 \mathrm{ab}$ & $0.53 \mathrm{defg}$ \\
\hline $\mathrm{SC} / \mathrm{P}$ & $0.13 a$ & $0.42 b$ & $0.43 a b$ & $0.54 \mathrm{ef}$ & & & & & $0.14 a b$ & $0.523 a$ & $0.61 \mathrm{ab}$ & $0.41 \mathrm{~g}$ \\
\hline$S / P$ & & & & & & & & & $0.13 a b$ & 0.57 & $0.69 \mathrm{ab}$ & $0.82 \mathrm{bcd}$ \\
\hline$C$ & $0.167 a$ & $0.40 \mathrm{~b}$ & $0.37 \mathrm{~b}$ & $0.60 \mathrm{dcef}$ & & & & & & & & \\
\hline $\mathrm{CL} / \mathrm{P}$ & $0.14 a$ & $0.48 b$ & $0.53 a b$ & $0.79 \mathrm{abcd}$ & $0.29 \mathrm{abc}$ & $1.003 \mathrm{abc}$ & $0.78 b$ & $0.63 f$ & & & & \\
\hline $\mathrm{CL}$ & $0.13 a$ & $0.44 b$ & $0.50 \mathrm{ab}$ & $0.73 \mathrm{abcde}$ & $0.31 \mathrm{abc}$ & $1.01 \mathrm{abc}$ & $0.87 a b$ & $0.59 \mathrm{f}$ & & & & \\
\hline $\mathrm{C} / \mathrm{R}$ & $0.15 a$ & $0.46 \mathrm{~b}$ & $0.40 \mathrm{ab}$ & $0.48 \mathrm{f}$ & & & & & & & & \\
\hline CL/R & $0.13 a$ & $0.537 \mathrm{~b}$ & $0.53 a b$ & $0.83 \mathrm{sbc}$ & $0.287 a b c$ & $1.34 a$ & $1 \mathrm{ab}$ & $2.3 a$ & & & & \\
\hline $\mathrm{CL} / \mathrm{P} / \mathrm{R}$ & 0.177 & $0.7 \mathrm{a}$ & $0.36 \mathrm{~b}$ & $0.81 \mathrm{abcd}$ & $0.38 a$ & $1.22 \mathrm{ab}$ & $0.72 \mathrm{~b}$ & $0.84 \mathrm{ef}$ & & & & \\
\hline $\mathrm{SE} \pm$ & 0.01 & 0.017 & 0.01 & 0.02 & 0.07 & & 0.04 & 0.05 & 0.006 & 0.02 & 0.017 & 0.02 \\
\hline $\mathrm{CV}$ & 29.7 & 25.7 & 21.4 & 18.08 & 15.8 & & 29.5 & 29.19 & 27.3 & 25.3 & 16.4 & 21.08 \\
\hline
\end{tabular}

Means with the same letter (s) within each column are not significantly different at 0.05 level using Duncan's Multiple Range Test.

Legend: $\mathrm{C}=$ Clitoria, $\mathrm{L}=$ lablab, $\mathrm{S}=$ sorghum, $\mathrm{P}=$ phosphors, $\mathrm{R}=$ Rhizobium 
Ratoon plants were thicker than the first crop plants. In the first year, lablab treated with $P$ and $R$ gained the thickest stems $(1.5$ and $1.46 \mathrm{~cm})$, whereas in the second year, LC/R produced the thickest stems $(2.3 \mathrm{~cm})$. Generally, lablab grown alone developed thicker stems.

Sorghum sudanense: There were significant differences in stem diameter (SD) throughout the different samplings and harvests except for the first sampling and first harvest in year one and the second sampling of year two.. Unlike Clitoria and lablab, sole sorghum in most treatments gave thinner stems compared with intercropping. The SD of the first cut of the two seasons did not reach $1 \mathrm{~cm}$ and in the last reading of the first year the SD ranged between 0.36 and $0.55 \mathrm{~cm}$, whereas first crop SD ranged between 0.56 and $0.82 \mathrm{~cm}$. Addition of $\mathrm{P}$ was observed to increase SD.

The SD of the ratoon plant was slightly thicker $(0.39$ to 0.91 for the first year and 0.4 to 1.11 for second year) compared with the first cut. In the first year, sorghum treated with $\mathrm{P}$ attained the thickest stems (0.91) and planting of three crops together resulted in thicker sorghum stem. Second year ratoon revealed that SL/R significantly scored the higher value of the SD $(1.11 \mathrm{~cm})$. Generally, addition of $P$ increased the SD.

\section{Leaf area $\left(\mathrm{cm}^{2}\right)$}

Clitoria ternatea: All readings were significantly different in the two seasons except the second reading of the second season. The leaf area of the Clitoria ranged between 3.43 to $55 \mathrm{~cm}^{2}$ for the first season and 9.32 to $57.26 \mathrm{~cm}^{2}$ for the second season (Tables $1 \mathrm{a}$ and $1 \mathrm{~b}$ ).

In the first reading of the first season, plants treated with phosphorus or inoculated with Rhizobium were not significantly different and even sole or intercropped treatments did not affect the size of the leaves. Second reading showed an observable increase in the leaf area, sole plants relatively scored the largest leaf area. Increase in leaf area due to addition of phosphorus was observed. Inoculation did not affect Clitoria leaf area.

At time of harvest, plant's leaf area reached the largest size compared with the previous readings. Clitoria: Lablab /R treatment resulted in plants with the largest leaves $\left(55 \mathrm{~cm}^{2}\right)$ whereas $C / R$ had the smallest leaf area $\left(32.27 \mathrm{~cm}^{2}\right)$. Intercropping of three plants resulted in smaller leaves. Effect of phosphorus was not statistically significant.
The leaf area of the ratoon plant was more or less similar to that of the first cut. Sole Clitoria treatment was the best one $\left(52.5 \mathrm{~cm}^{2}\right), C L S / R$ gained the smallest size $\left(29.3 \mathrm{~cm}^{2}\right)$. Although most of intercrop treatments were statistically not significant, but there were differences among means, in which mono-crops and double crops were having largest leaf areas. Phosphorus slightly increased the leaf area.

Second season (2006), first reading plants produced large leaves compared with the first reading of the first season. Clitoria: Lablab/P/R treatment revealed plants with the largest leaf size $\left(25.11 \mathrm{~cm}^{2}\right)$ and the $\mathrm{C} / \mathrm{P} / \mathrm{R}$ treatment resulted in the smallest leaf area $\left(9.32 \mathrm{~cm}^{2}\right)$. Intercropping, addition of phosphorus and inoculation did not significantly affect the leaf area. Even second reading was not significantly different; Clitoria: Lablab /P/R treatment gained the largest leaf area $\left(54.17 \mathrm{~cm}^{2}\right)$. Last reading showed significant difference among treatments. Clitoria treated with $\mathrm{P}$ and $R$ was the best treatment $\left(86.2 \mathrm{~cm}^{2}\right)$ with the largest leaf area throughout the two seasons. Clitoria: Sorghum: Lablab, CS/P/R, CL/P, CL/R, C/R and $\mathrm{CL} / \mathrm{P} / \mathrm{R}$ treatments were not significantly different. Intercropping Clitoria plant with sorghum resulted in smaller leaf area. Addition of either $\mathrm{P}$ or $\mathrm{R}$ to the soles and intercrops did not affect leaf area.

Ratoon plants showed smaller leaf area compared with the last reading of the first crop. Clitoria grown alone $(C)$ produced the largest leaf area $\left(50.17 \mathrm{~cm}^{2}\right)$. Clitoria: Sorghum: Lablab /P/R had the smallest leaf area $\left(24.28 \mathrm{~cm}^{2}\right)$. Inoculation relatively increased the leaf area. Phosphorus addition had no clear effect on the leaf area.

Lablab purpureus: All readings of the two seasons were significantly different except the second and the last reading of the first season. The leaf areas of lablab plant ranged between 13.6 to $167.9 \mathrm{~cm}^{2}$ for the first season and 16.76 to $235.25 \mathrm{~cm}^{2}$ for the second season.

First reading of the first season revealed L/P/R had the largest leaf area $\left(25.6 \mathrm{~cm}^{2}\right)$ and LCS/P/R had the smallest one $\left(13.6 \mathrm{~cm}^{2}\right)$, the rest of the means were not significantly different. Although there were very large differences between means, there were no significant differences in the second and last readings.

Leaf area in ratoon plants was significantly affected by treatments. Clitoria: Sorghum: Lablab /P/R treatment resulted in the largest leaf area $\left(167.9 \mathrm{~cm}^{2}\right)$ and SL was the smallest one $\left(45.4 \mathrm{~cm}^{2}\right)$. Rhizobium 
inoculation and addition of phosphorus at the same time increased the leaf area in different intercropping treatments.

In second season, first reading showed significant difference among treatments. Clitoria: Lablab /R and $L / P / R$ had the largest leaf areas $\left(93.25\right.$ and $92.87 \mathrm{~cm}^{2}$ respectively) and SL treatment gave the smallest leaf area $\left(16.76 \mathrm{~cm}^{2}\right)$. The effect of intercropping, $P$ and $R$ were not significant in this reading.

Second reading revealed significant variation among treatments. The maximum leaf area resulted from L/P/R treatment $\left(216.8 \mathrm{~cm}^{2}\right)$ which was not significantly different from $\mathrm{CL}$ and $\mathrm{CL} / \mathrm{P} / \mathrm{R}$ treatments; other treatments were not statistically different in leaf area.

At time of harvest plants produced large leaves. Lablab grown with sorghum and treated with $P$ resulted in the largest leaves $\left(235.25 \mathrm{~cm}^{2}\right)$, but this treatment was not significantly different from the rest of the treatments except, SL treatment which produced plants with the smallest leaves (124.29 $\mathrm{cm}^{2}$ ).

Ratoon crops were significantly variable in leaf areas due to the application of different treatments. Unlike most treatments, intercropping of the three crops (LCS) produced plants with larger leaves $\left(206.3 \mathrm{~cm}^{2}\right)$, whereas SL/R, L, LC/P, LC, LC/R and LC/P/R gave smaller leaves.

Sorghum sudanense: The leaf area of the plant under study ranged between 2.01 to $136.9 \mathrm{~cm}^{2}$ for the first season and 14.07 to $195.35 \mathrm{~cm}^{2}$ for the second season. There were significant differences among treatments in the two seasons except, second reading of the first season and first and second reading of the second season. Sorghum planted with Clitoria and sole sorghum (S) produced the largest leaves (6.56 and $6.35 \mathrm{~cm}^{2}$, respectively).

In spite of the lack of significance of the second reading, there was some degree of variation between means. Sorghum intercropped with lablab and treated with $\mathrm{P}$ was the best treatment with respect to leaf area $\left(75.2 \mathrm{~cm}^{2}\right)$. There was significant difference in the last reading. Clitoria: Sorghum: Lablab /R treatment produced the largest leaf area $\left(108 \mathrm{~cm}^{2}\right)$ and SC/R gave the smallest leaves $\left(60.4 \mathrm{~cm}^{2}\right)$.

Second cut revealed significant variation among treatments. Clitoria: Sorghum: Lablab /P/R treatment scored the largest leaf area $\left(136.9 \mathrm{~cm}^{2}\right)$, followed by SCL/P $\left(134.4 \mathrm{~cm}^{2}\right)$. The planting of the three crops together with addition of $\mathrm{P}$ significantly increased the leaf area of the sorghum. Sorghum grown with lablab relatively gave large leaf area compared to sorghum with Clitoria.

In the second season, first and second readings were not significant, but treatment means were highly variable. Intercropping increased the leaf area of sorghum plant in the first two readings, but phosphorus and Rhizobium had no effect. At time of harvest plots planted with two or three crops produced large leaves compared with sole crops. $\mathrm{P}$ and $R$ did not increase the leaf area. Second cut revealed significant difference between treatments, $P$ relatively increased the leaf area of sorghum. In general the two combinations intercropping gave larger leaf area.

Leaf-to-stem ratio: Leaf to stem ratio decreased with the increasing of plant age in the two seasons (Tables $3 a$ and $3 b$ ).

Clitoria ternatea : Treatments significantly affected L/S ratio in the two seasons and in all readings of the first crop except the last reading. During the first season the leaf to stem ratio ranged between 0.79 and 7.3, whereas in the second season it ranged between 1.01 and 8.8. In the first reading, generally the two-combination intercropping revealed higher ratios compared with three-combinations. The highest ratio (7.3) was obtained with sole Clitoria not treated, whereas $\mathrm{CL} / \mathrm{P} / \mathrm{R}$ was the lowest one. In most treatments, the ratio increased with the addition of phosphorus. Rhizobium inoculation did not clearly affect the ratio. Moreover, in the second reading the two crops combination and sole crops recorded the highest ratios. The effect of Rhizobium inoculation and phosphorus addition was not significantly different. Ratoon plants gave ratio between 1.07 and 2.07. The $S C / P / R$ and $C / P / R$ treatments scored the highest value.

In the second season CL treatment gave the highest ratio in the first reading and the rest of the treatments were not significantly different. In the second reading SC treatment obtained the highest score of 2.9 and SCL/P was the lowest treatment ratio. Third reading did not show any significant difference. Ratoon of second season revealed significant difference among treatments, CL/P/R was the highest one. 
Agric. Biol. J. N. Am., 2011, 2(1): 109-124

Table 2.a. Effect of intercropping, phosphorus and inoculation on leaf area (cm²) of Clitoria, lablab and sorghum (2005)

\begin{tabular}{|c|c|c|c|c|c|c|c|c|c|c|c|c|}
\hline \multirow[t]{2}{*}{ Treatment } & \multicolumn{4}{|c|}{ Clitoria } & \multicolumn{4}{|c|}{ Lablab } & \multicolumn{4}{|c|}{ Sorghum } \\
\hline & $\begin{array}{c}1^{\text {st }} \\
\text { reading }\end{array}$ & $\begin{array}{c}2^{\text {nd }} \\
\text { reading }\end{array}$ & $\begin{array}{c}\text { At } 1^{\text {st }} \\
\text { harvest }\end{array}$ & $\begin{array}{c}\text { At } 2^{\text {nd }} \\
\text { harvest }\end{array}$ & $\begin{array}{c}1^{\text {st }} \\
\text { reading }\end{array}$ & $\begin{array}{c}2^{\text {nd }} \\
\text { reading }\end{array}$ & $\begin{array}{c}\text { At } 1^{\text {st }} \\
\text { harvest }\end{array}$ & $\begin{array}{c}\text { At } 2^{\text {nd }} \\
\text { harvest }\end{array}$ & $\begin{array}{c}1^{\text {st }} \\
\text { reading }\end{array}$ & $\begin{array}{c}2^{\text {nd }} \\
\text { reading }\end{array}$ & $\begin{array}{c}\text { At } 1^{\text {st }} \\
\text { harvest }\end{array}$ & $\begin{array}{c}\text { At } 2^{\text {nd }} \\
\text { harvest }\end{array}$ \\
\hline $\mathrm{L} / \mathrm{P} / \mathrm{R}$ & & & & & $25.6 a$ & $112.9 a$ & $142.3 a$ & $85.7 a b$ & & & & \\
\hline $\mathrm{SCL}$ & $4.4 a b$ & $32.3 a b$ & $39.96 \mathrm{ab}$ & 41.1abc & $20.2 a b$ & $122.59 a$ & 143.a & 101.8 & $4.38 a b$ & $53.3 a$ & $80.2 \mathrm{ab}$ & $47.9 f$ \\
\hline $\mathrm{SC} / \mathrm{P} / \mathrm{R}$ & $4.79 a b$ & $27.96 a b$ & $38.23 a b$ & $39.3 a b c$ & & & & & $3.38 a b$ & $36.7 a$ & $75.1 \mathrm{ab}$ & 113.9abcd \\
\hline $\mathrm{SL}$ & & & & & $16.2 a b$ & $75.2 a$ & 120.a & $45.5 b$ & $4.6 a b$ & $40.2 a$ & $62.1 \mathrm{~b}$ & $129.4 a b$ \\
\hline SL /R & & & & & $16.91 \mathrm{ab}$ & $76.8 \mathrm{a}$ & $63 a$ & $88.02 \mathrm{ab}$ & $3.77 a b$ & $60.6 a$ & $67.6 \mathrm{ab}$ & 62.6ef \\
\hline $\mathrm{SL} / \mathrm{P}$ & & & & & 16.97ab & $73.2 a$ & $130.2 a$ & 127.3ab & $4.59 a b$ & $75.2 a$ & $70.8 \mathrm{ab}$ & $121.6 a b c$ \\
\hline SL/P/R & & & & & $23.72 a b$ & $95.7 a$ & $1375 a$ & $125.1 \mathrm{ab}$ & $5.69 a b$ & $67.7 a$ & $96.4 a b$ & 106.6abcd \\
\hline $\bar{L}$ & & & & & $23.3 b$ & $107 a$ & $15.4 a$ & $79.6 a b$ & & & & \\
\hline$L / P$ & & & & & $15.3 b$ & $10298 a$ & $100.8 a$ & $96.6 a b$ & & & & \\
\hline$S$ & & & & & & & & & $6.35 a$ & $39.6 a$ & $61.7 b$ & 116.4abcd \\
\hline SCL/P/R & $4.84 a b$ & $20.5 b$ & $39.6 a b$ & $48.73 a b$ & $13.6 b$ & $92.35 a$ & $139.4 a$ & $167.9 a$ & $3.28 \mathrm{ab}$ & $37.1 \mathrm{a}$ & $93.4 \mathrm{ab}$ & $136.9 a$ \\
\hline L/R & & & & & 17.64ab & $97.4 a$ & 118.5 & $117.84 \mathrm{ab}$ & & & & \\
\hline SCL/R & $4.96 a b$ & $31.87 a b$ & $47.4 a b$ & $29.3 a$ & $22.20 a b$ & $102.6 a$ & $85.9 a$ & $90.3 a b$ & $5.35 a b$ & $65.5 a$ & $108 a$ & $82.2 \mathrm{cdef}$ \\
\hline$\overline{S C L / P}$ & $5.8 a b$ & $41.2 a$ & $37.82 \mathrm{ab}$ & $32.7 \mathrm{bc}$ & $17.9 a b$ & $100.97 a$ & $148.2 a$ & $102.6 a b$ & $4.82 \mathrm{ab}$ & $49.2 a$ & $94.4 a b$ & 134.4ab \\
\hline $\mathrm{C} / \mathrm{P}$ & $4.22 a b$ & $36.6 a b$ & $38.22 a b$ & $44.97 a b c$ & & & & & & & & \\
\hline $\mathrm{C} / \mathrm{P} / \mathrm{R}$ & $3.43 b$ & $26.5 a b$ & $4.02 a b$ & $42.6 a b c$ & & & & & & & & \\
\hline SC & 4.62.ab & $22.97 \mathrm{~b}$ & $39.3 a b$ & $46.8 \mathrm{abc}$ & & & & & $6.56 a$ & $53.8 a$ & $75.3 a b$ & 88.5 bcdef \\
\hline $\mathrm{SC} / \mathrm{R}$ & $3.96 a b$ & $21.94 b$ & $37.7 a b$ & $47.94 a b c$ & & & & & $3.3 a b$ & $44.1 \mathrm{a}$ & 77.7ab & $48.3 f$ \\
\hline $\mathrm{SC} / \mathrm{P}$ & $4.01 \mathrm{ab}$ & $30.4 a b$ & $38.8 a b$ & $47.1 \mathrm{bc}$ & & & & & $2.01 \mathrm{~b}$ & $378 a$ & $60.4 a$ & 72.3edf \\
\hline $\mathrm{S} / \mathrm{P}$ & & & & & & & & & $4.93 a b$ & $49.5 a$ & $61.2 \mathrm{~b}$ & 79.7cdeg \\
\hline $\mathrm{C}$ & $4.52 \mathrm{ab}$ & $36.03 a b$ & $45.7 a b$ & $52.5 a$ & & & & & & & & \\
\hline $\mathrm{CL} / \mathrm{P}$ & $3.94 a b$ & $29.9 a b$ & $37.1 \mathrm{~b}$ & 36.abc & $20.3 a b$ & 100.6 & 125.a & $89.5 a b$ & & & & \\
\hline $\mathrm{CL}$ & $4.36 \mathrm{ab}$ & $31.98 a b$ & $39.85 a b$ & $44.7 a b c$ & 19.14ab & $98.1 \mathrm{a}$ & 132.a & $142.3 \mathrm{ab}$ & & & & \\
\hline $\mathrm{C} / \mathrm{R}$ & $3.66 \mathrm{~b}$ & $28.6 a b$ & $32.27 \mathrm{~b}$ & $41.9 a b c$ & & & & & & & & \\
\hline $\mathrm{CL} / \mathrm{R}$ & $5.2 \mathrm{ab}$ & $31.16 a b$ & $55 a$ & $46.9 a b c$ & $19.3 a b$ & $102.1 \mathrm{a}$ & $142.9 a$ & $68 \mathrm{ab}$ & & & & \\
\hline $\mathrm{CL} / \mathrm{P} / \mathrm{R}$ & $5.95 a b$ & $31.4 a b$ & $39.67 a b$ & $47 a b c$ & 17.89ab & $107.7 a$ & 112.2 & $118.5 \mathrm{ab}$ & & & & \\
\hline SE \pm & 0.16 & 1.04 & 1.08 & 1.1 & 0.36 & 4.4 & 6.2 & 6.6 & 0.3 & 3 & 3.4 & 3.7 \\
\hline $\mathrm{CV}$ & 23.8 & 23.9 & 18.7 & 17.6 & 22.6 & 30.8 & 35.4 & 43.2 & 42.9 & 44.4 & 28.6 & 25.5 \\
\hline
\end{tabular}

Means with the same letter (s) within each column are not significantly different at 0.05 level using Duncan's Multiple Range Test.

Legend: $C=$ Clitoria, $L=$ lablab, $S=$ sorghum, $P$ = phosphors, $R=$ Rhizobium 
Agric. Biol. J. N. Am., 2011, 2(1): 109-124

Table 2.b. Effect of intercropping, phosphorus and inoculation on leaf area of Clitoria, lablab and sorghum (2006)

\begin{tabular}{|c|c|c|c|c|c|c|c|c|c|c|c|c|}
\hline \multirow[b]{2}{*}{ Treatment } & \multicolumn{4}{|c|}{ Clitoria } & \multicolumn{4}{|c|}{ Lablab } & \multicolumn{4}{|c|}{ Sorghum } \\
\hline & $\begin{array}{c}1^{\text {st }} \\
\text { reading }\end{array}$ & $\begin{array}{c}2^{\text {nd }} \\
\text { reading }\end{array}$ & $\begin{array}{c}\text { At } 1^{\text {st }} \\
\text { harvest }\end{array}$ & $\begin{array}{c}\text { At } 2^{\text {nd }} \\
\text { harvest }\end{array}$ & $\begin{array}{c}1^{\text {st }} \\
\text { reading }\end{array}$ & $\begin{array}{c}2^{\text {nd }} \\
\text { reading }\end{array}$ & $\begin{array}{c}{\text { At } 1^{\text {st }}} \\
\text { harvest }\end{array}$ & $\begin{array}{c}\text { At } 2^{\text {nd }} \\
\text { harvest }\end{array}$ & $\begin{array}{c}1^{\text {st }} \\
\text { reading }\end{array}$ & $\begin{array}{l}2^{\text {nd }} \\
\text { reading }\end{array}$ & $\begin{array}{c}\text { At } 1^{\text {st }} \\
\text { harvest }\end{array}$ & $\begin{array}{c}\text { At } 2^{\text {nd }} \\
\text { harvest }\end{array}$ \\
\hline $\mathrm{L} / \mathrm{P} / \mathrm{R}$ & & & & & $92.87 a$ & $216.87 a$ & 199.74ab & $17.1 \mathrm{~b}$ & & & & \\
\hline SCL & $22.02 \mathrm{ab}$ & 46.37 & $57.25 a b$ & 44.94abcd & 71.79abc & $143.87 \mathrm{~b}$ & 199.16ab & $206.3 a$ & $47.29 a$ & $152.31 \mathrm{a}$ & $185.48 a$ & 125.72cdef \\
\hline $\mathrm{SC} / \mathrm{P} / \mathrm{R}$ & 15.10abc & $47.7 a$ & $58.82 \mathrm{ab}$ & $48.78 \mathrm{ab}$ & & & & & $33.38 a$ & $141.52 a$ & $111.9 \mathrm{~b}$ & $173.17 b$ \\
\hline $\mathrm{SL}$ & & & & & $16.76 c$ & $130.61 b$ & $124.29 b$ & $153.04 c$ & $14.07 a$ & $88.93 a$ & $100.87 b$ & $143.75 \mathrm{~cd}$ \\
\hline SL /R & & & & & 34.69abc & $137.84 b$ & 172.15ab & $108.8 \mathrm{e}$ & $14.88 a$ & $127.86 a$ & $97.65 b$ & 134.67 \\
\hline $\mathrm{SL} / \mathrm{P}$ & & & & & $44.75 a b c$ & $140.02 b$ & $235.25 \mathrm{~g}$ & $139.05 \mathrm{~cd}$ & $14.27 a$ & $118.8 \mathrm{a}$ & $115.29 b$ & 120.64def \\
\hline SL/P/R & & & & & $34.61 \mathrm{abc}$ & $108.59 \mathrm{~b}$ & $129.4 b$ & $146.53 c$ & $29.25 a$ & $121.8 \mathrm{a}$ & $117.19 b$ & $195.35 a$ \\
\hline $\mathrm{L}$ & & & & & 31.14 & $121.9 b$ & 199.36ab & 109.11 & & & & \\
\hline$L / P$ & & & & & 41.19abc & $132.55 b$ & $185.6 a b$ & $176.35 b$ & & & & \\
\hline $\mathrm{s}$ & & & & & & & & & $31.3 a$ & $121.2 \mathrm{a}$ & $108.98 b$ & $102.444 \mathrm{gf}$ \\
\hline SCL/P/R & 13.97abc & $49.2 a$ & $52.84 b$ & 43.91abcd & $22.14 b c$ & $136.48 b$ & $158.44 a b$ & $181.11 \mathrm{~b}$ & $26.27 a$ & $136.36 a$ & 131.46ab & $135.44 \mathrm{~cd}$ \\
\hline L/R & & & & & $45.32 a b c$ & $139 \mathrm{~b}$ & $190.18 a b$ & $129.87 \mathrm{de}$ & & & & \\
\hline SCL/R & 18.62abc & 49.59 & $52.84 a$ & 43.91abcd & 69.59abc & $131.7 b$ & 152.33ab & 121.3ed & $22.93 a$ & $144.02 \mathrm{~s}$ & $122.64 b$ & $84.55 \mathrm{~g}$ \\
\hline SCL/P & 18.62abc & $49.59 a$ & $50.55 b$ & $34.33 f$ & $68.57 a b c$ & 180.2ab & 179.34 & $135.37 \mathrm{~cd}$ & 32.53 & 163.98 & 131.42 & 126.59 \\
\hline $\mathrm{C} / \mathrm{P}$ & 13.3 & $40.96 a$ & $45 \mathrm{~b}$ & $45 \mathrm{~b}$ & & & & & & & & \\
\hline $\mathrm{C} / \mathrm{P} / \mathrm{R}$ & $9.32 \mathrm{c}$ & $41.96 a$ & $86.2 a$ & 44.45abcd & & & & & & & & \\
\hline SC & $12.54 \mathrm{bc}$ & $41.67 a$ & $49.62 b$ & 41.59abcdf & & & & & $14.87 a$ & $116.05 a$ & $124.76 \mathrm{~b}$ & 123.77cdef \\
\hline $\mathrm{SC} / \mathrm{R}$ & $21.1 \mathrm{abc}$ & $52.2 a$ & $49.23 b$ & & & & & & $19.22 a$ & $132.21 a$ & 151.07ab & 108.93ef \\
\hline $\mathrm{SC} / \mathrm{P}$ & 13.53abc & $40.88 a$ & $45.29 b$ & $39.68 \mathrm{cdef}$ & & & & & $18.64 a$ & $104.07 a$ & $93.91 b$ & 140.33 \\
\hline $\mathrm{S} / \mathrm{P}$ & & & & & & & & & $17.32 a$ & $91.42 a$ & $111.89 \mathrm{~b}$ & $145.57 \mathrm{c}$ \\
\hline $\mathrm{C}$ & 15.88abc & $48.07 a$ & $46.65 b$ & $50.17 a$ & & & & & & & & \\
\hline $\mathrm{CL} / \mathrm{P}$ & 14.10abc & $43.8 \mathrm{a}$ & $57.26 \mathrm{ab}$ & $36.99 \mathrm{ef}$ & 40.99abc & $130.87 \mathrm{~b}$ & 155.76ab & $104.71 \mathrm{e}$ & & & & \\
\hline $\mathrm{CL}$ & $15.18 \mathrm{abc}$ & $40.06 a$ & $47.74 b$ & 39.13 & $54.96 \mathrm{ac}$ & $162.07 \mathrm{ab}$ & 161.93ab & $105.8 \mathrm{e}$ & & & & \\
\hline $\mathrm{C} / \mathrm{R}$ & $11.93 \mathrm{bc}$ & $40.64 a$ & $54.34 a b$ & 41.79bdce & & & & & & & & \\
\hline CL/R & 19.91abc & $50.3 a$ & $54.46 a b$ & $42.0 \mathrm{bcde}$ & $93.25 a$ & $130.77 b$ & 201.51ab & 112.48 & & & & \\
\hline $\mathrm{CL} / \mathrm{P} / \mathrm{R}$ & $25.11 a$ & 54.17 & $54.60 \mathrm{ab}$ & 46.91abc & $88.03 a b$ & $180.4 a b$ & 184.74 & $114.15 \mathrm{e}$ & & & & \\
\hline SE \pm & 0.87 & 1.3 & 2.43 & 0.56 & 4.91 & 5.5 & 6.76 & 1.58 & 3.39 & 6.2 & 4.66 & 1.92 \\
\hline $\mathrm{CV}$ & 14.5 & 19.5 & 31.5 & 9.3 & 59.51 & 26.2 & 26.5 & 7.86 & 88.8 & 31.7 & 24.8 & 9.29 \\
\hline
\end{tabular}

Means with the same letter (s) within each column are not significantly different at 0.05 level using Duncan's Multiple Range Test. Legend: $\mathrm{C}=$ Clitoria, $\mathrm{L}=$ lablab, $\mathrm{S}=$ sorghum, $\mathrm{P}=$ phosphors, $\mathrm{R}=$ Rhizobium 
Lablab purpureus: Treatments were significantly different in the two seasons, except in the first reading of the first season. Leaf to stem ratio ranged between 0.45 and 6.7 in the first season and 0.95 to 6.9 in the second season. Although the first reading in the first season was not significant, some variations found among the means in which $\mathrm{CL}$ got the highest ratio. Addition of phosphorus to the plants slightly increased the ratio. The three-combination intercropped treatments gained the lesser ratios to some extent compared with soles and two intercrops. Means were significantly different in the second reading. Lablab plants treated with phosphorus (L/P) gave the highest ratio of 3.16. Lablab: Clitoria / Rhizobium and LC/P/R were significantly lower than $L / P$ plots. At the time of harvest L/R significantly recorded the highest ratio, whereas the LCS/P was the lowest treatment. The average leaf to stem ratio of the first season ratoon was similar to the average of the last reading. Lablab /P showed the highest ratio (2.07) and LC/R combination ranked the lowest.

In the second season, leaf to stem ratio of lablab in all readings was significantly affected by treatments. Not like other readings, in the first reading, the intercropping of the three crops (LSC/P) gave the higher ratio, otherwise soles and two intercropped plots obtained the best results. Phosphorus addition in most cases increased the ratio.

Clitoria: Lablab /P/R revealed the higher figure (3.54) followed by LCS and LS was the lower ratio in the second reading, other treatments were not significantly different. At time of harvest lablab grown alone obtained the highest ratio of 1.74 , phosphorus and Rhizobium were not clearly affecting the ratio. Ratoon plants were significantly varied with treatments, LC/P/R (2.7) was the best treatment, addition of phosphorus and Rhizobium were not affecting the ratio.

Sorghum sudanense: First season did not reveal any significant variation, but in the second season all readings showed significant differences among treatments. Leaf to stem ratio ranged between 0.67 to 3.46 for the first season and 0.45 to 24.1 for the second season.

In the second, SC treatment gave the highest ratio of 24.1 in the first reading, the rest of the treatments were statistically not significant. In second reading, addition of phosphorus increased the ratio; intercropping and Rhizobium did not increase the ratio. At the time of harvest SC treatment gave the highest ratio. Although, treatments were significantly different in ratoon, the ratio was not obviously affected by inoculation and intercropping, but it was increased in most cases by addition of phosphorus.

Nodulation: This parameter was measured after 6 weeks from planting and at the time of harvest.

\section{Clitoria ternatea}

Number of nodules: In the first season, nodule counts were significantly increased $(P<0.05)$ with the addition of phosphorus in the first reading, in which Clitoria intercropped with sorghum gained the highest number (16.44) but at the time of harvesting nodule number were not affected by neither phosphorus nor intercropping in spite of its significant difference (Table 4).

In general, at the time of harvesting the nodule number tended to decrease. In the second reading, significant difference appeared among treatments, sole Clitoria plants obtained the highest number of nodules per plant (11.44). In the second season number of nodules per plant increased and the treatments were not significantly different in the first reading, but sole Clitoria plant got the highest number

In the last reading there was significant difference among treatments. The total number of nodules decreased, the treatment (SCL/P/R) gave the highest nodulation with an average of 47.67 nodules per plant. Generally phosphorus had more effect on nodule number than Rhizobium inoculation in the same treatments.

In both seasons, the average number of nodules per plant decreased with the progresses of plant growth towards maturity. Nodules number decreased from 6.52 to 3.32 in the first season and from 34.81 to 16.53 in the second season.

Weight of nodules (gram): In the first season, weight of nodules was not significantly different between treatments in the first reading, but there were slight differences between means where the treatment (SCL/P/R) gained the heaviest weight (Table 5). In the second reading, treatments were significantly different in weight of nodules; sole Clitoria weighed the heaviest nodules with the mean of $0.6 \mathrm{~g}$ per nodules per plant.

In the second season nodule weight did not show any significant variation in the first reading, but at the time of harvest it revealed significant difference among treatment means. Treatment $C / P / R$, gained the heaviest weight. The average nodule weight per plant ranged between 0.083 to 0.158 and 0.40 to $0.74 \mathrm{~g}$ per plant for the first and second season, respectively. 
Agric. Biol. J. N. Am., 2011, 2(1): 109-124

Table 3.a. Effect of intercropping, phosphorus and inoculation on leaf to stem ratio of Clitoria, lablab and sorghum (2005)

\begin{tabular}{|c|c|c|c|c|c|c|c|c|c|c|c|c|}
\hline \multicolumn{4}{|c|}{ Sorghum } & \multicolumn{4}{|c|}{ Lablab } & \multicolumn{4}{|c|}{ Clitoria } & \multirow[b]{2}{*}{ Treatment } \\
\hline $\begin{array}{c}\text { At } 2^{\text {nd }} \\
\text { harvest }\end{array}$ & $\begin{array}{c}\text { At } 1^{\text {st }} \\
\text { harvest }\end{array}$ & $\begin{array}{c}2^{\text {nd }} \\
\text { reading }\end{array}$ & $\begin{array}{c}1^{\text {st }} \\
\text { reading }\end{array}$ & $\begin{array}{c}\text { At } 2^{\text {nd }} \\
\text { harvest }\end{array}$ & $\begin{array}{c}\text { At } 1^{\text {st }} \\
\text { harvest }\end{array}$ & $\begin{array}{c}2^{\text {nd }} \\
\text { reading }\end{array}$ & $\begin{array}{c}1^{\text {st }} \\
\text { reading }\end{array}$ & $\begin{array}{c}\text { At } 2^{\text {nd }} \\
\text { harvest }\end{array}$ & $\begin{array}{c}\text { At } 1^{\text {st }} \\
\text { harvest }\end{array}$ & $\begin{array}{c}2^{\text {nd }} \\
\text { reading }\end{array}$ & $\begin{array}{c}1^{\text {st }} \\
\text { reading }\end{array}$ & \\
\hline & & & & $1.48 \mathrm{abcd}$ & $1.52 b c$ & $2.30 a b$ & $4.05 a$ & & & & & $L / P / R$ \\
\hline $0.87 a$ & $0.66 a$ & $1.08 a$ & $2.6 a$ & $0.77 \mathrm{de}$ & $1.70 \mathrm{bc}$ & $2.90 a b$ & $5.22 a$ & 1.57abcdef & $1.29 a$ & $2.08 a b$ & $3.3 a b$ & $\mathrm{SCL}$ \\
\hline $1.23 a$ & 0.92 & $1.83 a$ & 2.33 & & & & & $2.07 a$ & $1.32 a$ & $2.04 a b$ & 4 & SC/P/R \\
\hline $1.27 \mathrm{a}$ & 0.75 & $0.77 a$ & $1.67 a$ & $0.70 \mathrm{de}$ & $1.90 \mathrm{abc}$ & 1.83ab & $4.18 a$ & & & & & $\mathrm{SL}$ \\
\hline $1.23 a$ & $1.07 a$ & $1.44 a$ & 3.36 & $1.77 a b c$ & $2.93 a$ & $2.23 a b$ & $5.83 a$ & & & & & SL /R \\
\hline $1.20 \mathrm{a}$ & $0.59 a$ & $0.83 a$ & $1.53 a$ & 1.17abcde & $1.72 \mathrm{bc}$ & $2.51 \mathrm{ab}$ & $6 a$ & & & & & SL/P \\
\hline \multirow[t]{3}{*}{$1.10 a$} & $0.57 a$ & $1.11 \mathrm{a}$ & $1.53 a$ & 1.33 & $1.53 b c$ & 1.94 & $4.4 a$ & & & & & SL/P/R \\
\hline & & & & $1.7 a b c$ & $1.43 b c$ & $2.25 \mathrm{ab}$ & $5.03 a$ & & & & & $\mathrm{~L}$ \\
\hline & & & & $2.07 a$ & $2.21 \mathrm{abc}$ & $3.16 a$ & $4.5 a$ & & & & & $\mathrm{~L} / \mathrm{P}$ \\
\hline $1.23 a$ & $1.28 a$ & $1.01 \mathrm{a}$ & $1.58 \mathrm{a}$ & & & & & & & & & $S$ \\
\hline \multirow[t]{2}{*}{0.8} & $1.20 \mathrm{a}$ & $1.33 a$ & $1.63 a$ & $0.63 \mathrm{de}$ & $1.49 \mathrm{bc}$ & 1.87 & $4.78 a$ & $1.83 \mathrm{abc}$ & $1.23 a$ & $0.93 b$ & $4 a b$ & SCL/P/R \\
\hline & & & & $1.3 a b$ & $1.2 \mathrm{c}$ & $2.55 a b$ & $5.11 a$ & & & & & $L / R$ \\
\hline $0.67 a$ & $0.64 a$ & $1.38 a$ & $1.57 \mathrm{a}$ & $1.03 \mathrm{bcde}$ & $1.60 \mathrm{bc}$ & 1.99ab & 4.11 & $1.3 \mathrm{cdef}$ & $1.36 a$ & $1.88 \mathrm{ab}$ & $2.3 a b$ & SCL/R \\
\hline \multirow[t]{2}{*}{$1.10 a$} & $0.62 a$ & $1.82 a$ & $2 a$ & $0.93 \mathrm{bcde}$ & $1.16 \mathrm{c}$ & $2.26 a b$ & $5.8 a$ & 1.67abcde & $1.097 a$ & $1.66 \mathrm{ab}$ & $5.8 a b$ & SCL/P \\
\hline & & & & & & & & $1.47 \mathrm{bcdef}$ & $1.26 \mathrm{a}$ & $1.84 \mathrm{ab}$ & $2.7 a b$ & $\mathrm{C} / \mathrm{P}$ \\
\hline 0.97 & $0.79 a$ & $.072 a$ & $1.5 a$ & & & & & $2.07 a$ & 1.046 & $1.77 a b$ & $3.1 \mathrm{ab}$ & C/P/R \\
\hline 0.67 & $0.68 a$ & $1.47 a$ & $3.33 a$ & & & & & $1.23 \mathrm{ef}$ & $1.25 a$ & $2.98 a$ & $4.5 a b$ & SC \\
\hline $0.9 a$ & $1.35 a$ & $1.35 a$ & $3 a$ & & & & & $1.8 \mathrm{abcd}$ & $1.053 a$ & $1.87 \mathrm{ab}$ & $5.8 a b$ & $\mathrm{SC} / \mathrm{R}$ \\
\hline \multirow[t]{8}{*}{$1.2 \mathrm{a}$} & $1.30 \mathrm{a}$ & $1.41 \mathrm{a}$ & $1.8 \mathrm{a}$ & & & & & $1.07 f$ & $0.91 a$ & 1.75 & $5.3 a b$ & $\mathrm{SC} / \mathrm{P}$ \\
\hline & & & & & & & & & & & & $S / P$ \\
\hline & & & & & & & & $2 a b$ & $1.03 a$ & $2.05 a b$ & $7.3 a$ & C \\
\hline & & & & & & & & $1.45 \mathrm{bcde}$ & $1.025 a$ & $1.4 a b$ & $4.5 a b$ & $\mathrm{CL/P}$ \\
\hline & & & & & & & & 1.53abcdef & $1.21 \mathrm{a}$ & 1.97 & $5 a b$ & $\mathrm{CL}$ \\
\hline & & & & & & & & $1.87 \mathrm{abc}$ & $1.46 a$ & 1.49 & $7 a b$ & $\mathrm{C} / \mathrm{R}$ \\
\hline & & & & $0.45 \mathrm{e}$ & $1.71 \mathrm{bc}$ & $1.50 \mathrm{~b}$ & $5 a$ & 1.56abcdef & $1.28 a$ & $1.75 a b$ & $5 a b$ & $\mathrm{CL} / \mathrm{R}$ \\
\hline & & & & $1.05 \mathrm{bcde}$ & $2.53 a b$ & $1.54 b$ & $5.5 a$ & $1.25 \mathrm{def}$ & $0.79 a$ & 1.39ab & $2 b$ & $\mathrm{CL} / \mathrm{P} / \mathrm{R}$ \\
\hline 0.05 & 0.09 & 0.13 & 0.17 & 0.06 & 0.07 & 0.09 & 0.22 & 0.03 & 0.04 & 0.12 & 0.3 & $\mathrm{SE} \pm$ \\
\hline 32.9 & 63.8 & 65.1 & 51.9 & 33.69 & 28.95 & 30.02 & 30.7 & 14.7 & 26.4 & 40 & 50.6 & $\mathrm{CV}$ \\
\hline
\end{tabular}

Means with the same letter (s) within each column are not significantly different at 0.05 level using Duncan's Multiple Range Test.

Legend: $C=$ Clitoria, $L=$ lablab, $S=$ sorghum, $P=$ phosphors, $R=$ Rhizobium 
Agric. Biol. J. N. Am., 2011, 2(1): 109-124

Table 3.b. Effect of intercropping, phosphorus and inoculation on leaf to stem ratio of Clitoria, lablab and sorghum (2006)

\begin{tabular}{|c|c|c|c|c|c|c|c|c|c|c|c|c|}
\hline \multicolumn{4}{|c|}{ Sorghum } & \multicolumn{4}{|c|}{ Lablab } & \multicolumn{4}{|c|}{ Clitoria } & \multirow[b]{2}{*}{ Treatment } \\
\hline $\begin{array}{c}\text { At }^{\text {nd }} \\
\text { harvest }\end{array}$ & $\begin{array}{c}{\text { At } 1^{\text {st }}} \\
\text { harvest }\end{array}$ & $\begin{array}{c}2^{\text {nd }} \\
\text { reading }\end{array}$ & $\begin{array}{c}1^{\text {st }} \\
\text { reading }\end{array}$ & $\begin{array}{c}\text { At }^{\text {nd }} \\
\text { harvest }\end{array}$ & At $1^{\text {st }}$ harvest & $2^{\text {nd }}$ reading & $\begin{array}{c}1^{\text {st }} \\
\text { reading }\end{array}$ & $\begin{array}{c}\text { At 2 }^{\text {nd }} \\
\text { harvest }\end{array}$ & $\begin{array}{c}{\text { At } 1^{\text {st }}} \\
\text { harvest }\end{array}$ & $\begin{array}{c}2^{\text {nd }} \\
\text { reading }\end{array}$ & $\begin{array}{c}1^{\text {st }} \\
\text { reading }\end{array}$ & \\
\hline & & & & $1.9 \mathrm{bc}$ & 1.15abcdef & $2.51 \mathrm{bcde}$ & $3.1 \mathrm{~b}$ & & & & & $L / P / R$ \\
\hline $0.8 d$ & $0.41 a$ & $0.77 \mathrm{ab}$ & $18.8 b$ & $1.14 \mathrm{de}$ & $1.023 \mathrm{bcdef}$ & $3.51 \mathrm{a}$ & $3.7 \mathrm{~b}$ & $1.64 \mathrm{bcdef}$ & $0.95 a$ & $2.2 a b c$ & $5.6 \mathrm{~b}$ & SCL \\
\hline $1.04 \mathrm{bcd}$ & $0.68 a b$ & $1.96 a b$ & $5.48 b$ & & & & & $2.17 a b$ & $0.85 a$ & $2.13 \mathrm{abc}$ & $3.65 b$ & $\mathrm{SC} / \mathrm{P} / \mathrm{R}$ \\
\hline $1.18 a b c$ & $0.92 \mathrm{ab}$ & $0.53 a b$ & $20.9 b$ & $1.1 \mathrm{de}$ & $1.56 \mathrm{abc}$ & $1.73 e$ & $4.2 \mathrm{ab}$ & & & & & SL \\
\hline $1.34 a$ & $0.93 a b$ & 1.14ab & $12.6 \mathrm{~b}$ & $1.95 b c$ & $1.6 a b$ & 2.6abcdef & $4.6 a b$ & & & & & SL /R \\
\hline $0.97 \mathrm{bcd}$ & $0.88 a b$ & $0.87 a b$ & $6.9 \mathrm{~b}$ & $1.04 \mathrm{e}$ & $1.63 \mathrm{ab}$ & 2.77abcd & $3.7 \mathrm{~b}$ & & & & & SL/P \\
\hline \multirow[t]{3}{*}{$1.01 \mathrm{bcd}$} & $0.61 \mathrm{ab}$ & $1.51 \mathrm{ab}$ & $4.6 \mathrm{~b}$ & $1.63 \mathrm{bcd}$ & $1.53 a b c d e$ & $2.14 \mathrm{edc}$ & 3.4 & & & & & SL/P/R \\
\hline & & & & $1.67 \mathrm{bcd}$ & $1.74 a$ & $1.8 \mathrm{de}$ & 4.3ab & & & & & $L$ \\
\hline & & & & $2.07 \mathrm{~b}$ & $0.89 \mathrm{dfe}$ & $2.9 a b c$ & $4.7 a b$ & & & & & $\mathrm{~L} / \mathrm{P}$ \\
\hline $1.27 a b$ & 0.706 & $0.69 b$ & $5.5 b$ & & & & & & & & & $S$ \\
\hline \multirow[t]{2}{*}{1.01} & 0.76 & $2.04 a$ & $2.4 \mathrm{~b}$ & $1.9 \mathrm{bc}$ & $1.097 \mathrm{bcdf}$ & 2.1 cde & $3.6 \mathrm{~b}$ & 1.9abcd & $1.07 a$ & 1.13de & $3.4 b$ & SCL/P/R \\
\hline & & & & $2.0 \mathrm{bc}$ & 1.47abcde & 2.71abcde & $3.9 \mathrm{~b}$ & & & & & L/R \\
\hline $1.08 \mathrm{abcd}$ & $0.76 \mathrm{ab}$ & $1.74 a b$ & $5.5 b$ & $1.34 \mathrm{cde}$ & $0.95 \mathrm{cdef}$ & 2.37bcde & $3.01 b$ & $1.5 \mathrm{egdf}$ & $0.99 a$ & $1.97 \mathrm{abcd}$ & $3.8 \mathrm{~b}$ & SCL/R \\
\hline \multirow[t]{3}{*}{$1.0 \mathrm{bcd}$} & 0.57 & $1.4 \mathrm{ab}$ & $20.13 b$ & 1.3de & 1.24abcdef & 2cde & $6.9 a$ & $1.47 \mathrm{def}$ & $1.03 a$ & $1.01 \mathrm{~d}$ & $3.2 b$ & SCL/P \\
\hline & & & & & & & & $1.24 \mathrm{gf}$ & $1.1 \mathrm{a}$ & 1.92abcd & $3.2 b$ & $\mathrm{C} / \mathrm{P}$ \\
\hline & & & & & & & & $2.06 a b c$ & $1.1 \mathrm{a}$ & $1.8 \mathrm{bde}$ & $3.5 b$ & $\mathrm{C} / \mathrm{P} / \mathrm{R}$ \\
\hline $0.97 \mathrm{bcd}$ & $1.06 a$ & $0.86 a b$ & $74.1 \mathrm{a}$ & & & & & $1.02 \mathrm{~g}$ & $1.2 \mathrm{a}$ & $2.9 a$ & $5.2 b$ & SC \\
\hline $1.04 \mathrm{bcd}$ & $0.57 a b$ & $1.5 \mathrm{ab}$ & $10.8 b$ & & & & & 1.7abcde & $1.08 a$ & $2.4 a b$ & $4.2 \mathrm{~b}$ & $\mathrm{SC} / \mathrm{R}$ \\
\hline $0.9 \mathrm{~cd}$ & $0.55 \mathrm{ab}$ & 1.14ab & $3.07 b$ & & & & & $1.07 \mathrm{~g}$ & $1.02 a$ & $1.73 \mathrm{bcd}$ & $3.9 b$ & SC/P \\
\hline \multirow[t]{7}{*}{0.93} & $0.45 b$ & $0.72 \mathrm{ab}$ & $5.9 \mathrm{~b}$ & & & & & & & & & $\mathrm{~S} / \mathrm{P}$ \\
\hline & & & & & & & & 1.816abcd & $1.22 \mathrm{a}$ & $1.57 \mathrm{bcd}$ & $4.6 \mathrm{~b}$ & C \\
\hline & & & & 1.15de & $0.64 f$ & $1.98 \mathrm{cde}$ & $3.9 \mathrm{~b}$ & 1.48defg & 1.15 & $2.2 \mathrm{abc}$ & $4.4 \mathrm{~b}$ & $\mathrm{CL} / \mathrm{P}$ \\
\hline & & & & $0.95 e$ & $0.79 f$ & $1.81 \mathrm{de}$ & $4.4 a b$ & 1.32egf & $1.16 a$ & $1.43 \mathrm{bcd}$ & $12.8 a$ & $\mathrm{CL}$ \\
\hline & & & & & & & & 1.9abcd & $1.1 \mathrm{a}$ & 1.83abcd & $2.7 \mathrm{~b}$ & $\mathrm{C} / \mathrm{R}$ \\
\hline & & & & $2.1 \mathrm{~b}$ & 1.17abcdef & $3.15 a b$ & $3.9 b$ & 2.03abcd & $1.35 a$ & 2.04abcd & $4.2 b$ & $\mathrm{CL} / \mathrm{R}$ \\
\hline & & & & $2.7 a$ & 1.077abcde & $3.54 a$ & $3.3 b$ & $2.27 a$ & $1.35 a$ & $2.13 a b c$ & $3.2 b$ & $\mathrm{CL} / \mathrm{P} / \mathrm{R}$ \\
\hline 0.2 & 0.05 & 0.1 & 9.1 & 0.039 & 0.05 & 0.8 & 2.21 & 0.04 & 0.04 & 0.08 & 0.57 & $\mathrm{SE} \pm$ \\
\hline 12.8 & 41.3 & 55.7 & 139.4 & 16.9 & 27.7 & 21.04 & 36.62 & 17.7 & 22.8 & 28.7 & 88 & CV \\
\hline
\end{tabular}

Means with the same letter (s) within each column are not significantly different at 0.05 level using Duncan's Multiple Range Test.

Legend: $\mathrm{C}=$ Clitoria, $\mathrm{L}=$ lablab, $\mathrm{S}=$ sorghum, $\mathrm{P}=$ phosphors, $\mathrm{R}=$ Rhizobium 


\section{Lablab purpureus}

Number of nodules: In 2005 season treatments were significantly different in number of nodules in the first reading. Nodules count ranged between 35.45 to 4.89 per plant (Table 4). After 6 weeks from planting (first reading) lablab intercropped with Clitoria scored the highest number, whereas lablab treated with phosphorus and Rhizobium gained the lowest number. At the time of harvest, treatments were significantly different. The total nodule number per plant decreased in a range of 17.45 to 2.22. The treatment $(\mathrm{LC} / \mathrm{P} / \mathrm{R})$ recorded the highest number of 17.45 per plant, and L/P scored the lowest number In 2006 season (second season) nodule number was significantly different in the first reading and nodule numbers ranged between 39.67 to 10.7 . Sole lablab treated with phosphorus gave the highest number of nodules (39.67), whereas L/P/R scored 10.7 nodules per plant. In the last reading, although there were large differences between means, treatments were not significantly different . Clitoria: Lablab /P/R scored the highest number of nodules (35.7) and SCL/R scored the lowest number (6.7). In general, nodule numbers decreased at the time of harvest, and they ranged between 6.7 to 35.7 with an average of 18.75 nodules per plant compared with 24.13 nodules per plant in the first reading.

Weight of nodules (g): Lablab nodule weights were significantly different $(P<0.0001)$ with intercropping, phosphorus and Rhizobium inoculation in the first season in both readings (Table 5). The average nodule weight per plant was $0.783 \mathrm{~g}$ for the first reading and $0.775 \mathrm{~g}$ for the second reading. In the first reading, $C / L$ combination resulted in the heaviest weight $(3 \mathrm{~g})$, means of $S C L / P / R$ and $L / R$ treatments were slightly higher than the rest of means and $S / L$ combination recorded the lowest nodule weight. At time of harvest, SCL/P treatments showed the heaviest weight $(3.5 \mathrm{~g})$ the remaining treatments were not significantly different.

In the second season, there were significant differences in both readings. The average nodule weight was $1.88 \mathrm{~g}$ for the first reading and $1.41 \mathrm{~g}$ per plant for the second reading. In 2005, the heaviest weight was recorded for the L/P treatment $(4.83 \mathrm{~g})$ followed by $C L / P / R$ treatment. At time of harvest L/P/R, SCL, SL/R, SL/P/R, L, SCL/P/R, LR and CL/P were not significantly different in nodule weight. In general plots not treated with phosphorus gave lightest nodules.
Prussic acid (ppm): Hydrocyanic acid (HCN) was measured at harvesting time for both first and second crops (Table 6). Intercropping and Rhizobium inoculation did not significantly affect the amount of $\mathrm{HCN}$ in sorghum plant tissues in the two seasons.

In the first season, there were significant differences in HCN both first crop and ratoon. In first crop, sorghum plant in SL treatment produced the highest amount of $\mathrm{HCN}(187.02)$ whereas SC/P recorded the lowest value (133.1). The sole sorghum treated with phosphorus contained lesser amount of $\mathrm{HCN}$ than untreated plant of about $25 \mathrm{ppm}$. In ratoon plants, $\mathrm{SC} / \mathrm{R}$ treatment resulted in sorghum plant with the highest amount of $\mathrm{HCN}$ (162.1), whereas SCL/P obtained the lowest value (138.4).

In the second season first crop and ratoon ( $2^{\text {nd }}$ cut) showed significant difference among treatments. The higher amount (ppm) of $\mathrm{HCN}$ was observed in sorghum plants not treated with phosphorus. In the first crop SL recorded the highest value of156.19 ppm and the lowest HCN (132.3 ppm) was recorded in $S / P$ treatment. Intercropping did not affect the amount of $\mathrm{HCN}$. In ratoon, $\mathrm{HCN}$ of sorghum plants was significantly affected by addition of phosphorus. Sorghum in SCL combination produced the highest HCN (159.8) whereas sorghum plant in (SL/P/R) combinations produced the lowest value (130.9).

\section{DISCUSSION}

Stem thickness was significantly affected by intercropping and addition of phosphorus. Sole crops were pronounced to produce forage with thicker stems in the first crop, but intercropped plants treated with $\mathrm{P}$ developed thicker stems during the second cut (ratoon). In the first case (sole crop), phosphorus probably had a role in cell division and in the other metabolic processes of the plant which resulted in increase of stem diameter. Plant population also affected stem thickness. In the second cut (ratoon), due to decrease in ratoon plant population, stem diameter increased due to the less competition.

Prussic acid: The poisonous substance $(\mathrm{HCN})$ in sorghum significantly decreased with $\mathrm{P}$ treatment and this is in agreement with Abusuwar (2005) who stated that addition of phosphorus and organic fertilizer decreased the $\mathrm{HCN}$ concentration. On the other hand, untreated plants accumulated high amount of $\mathrm{HCN}$ in the tissues.

Nodulation: In general Clitoria in intercropping treated with $\mathrm{P}$ and inoculated with Rhizobium gained high number and weight of nodules. This could be 
due to the concentration of $\mathrm{P}$ in nodules is higher than any other parts of plant (Sa and Israel, 1991) and in most cases phosphorus increased nodulation, and by doing so increased nitrogen resulted in increasing of crude protein content (Hague and Mohamed, 1985). Under severe $P$ deficiency condition in some legume, nodule formation is completely stopped (Almeida, et al. 2000). Phosphorus deficiency limits nodule development and growth more than that of the other organs (Drevon and Hartwig, 1997).
Some unexpected results have been found such as untreated sole plants produced high number and weight of nodule which indicated that experimental field may contain some endogenous Rhizobium strains of lablab and Clitoria. Lablab planted with Clitoria treated with $\mathrm{P}$ and $\mathrm{R}$ revealed more nodulation which may justify the importance of Rhizobium strain in the inoculation process. Phosphorus plays a vital role in energy transfer, metabolic regulation, phospholipids, DNA and RNA (Plaxton et al., 1989).

Table 4 Effect of intercropping, phosphorus and inoculation on nodule No. of Clitoria and lablab

\begin{tabular}{|c|c|c|c|c|c|c|c|c|}
\hline \multirow{3}{*}{ Treatment } & \multicolumn{4}{|c|}{ 1st season } & \multicolumn{4}{|c|}{ 2nd season } \\
\hline & \multicolumn{2}{|c|}{ Clitoria } & \multicolumn{2}{|r|}{ Lablab } & \multicolumn{2}{|r|}{ Clitoria } & \multicolumn{2}{|c|}{ Lablab } \\
\hline & 6th week & $\begin{array}{c}\text { At } \\
\text { harvest }\end{array}$ & 6th week & At harvest & 6th week & At harvest & 6th week & At harvest \\
\hline SCL & $8.98 a b$ & $3.33 a b$ & $6.11 \mathrm{~b}$ & $14.22 \mathrm{abc}$ & $41.67 \mathrm{a}$ & $18.33 \mathrm{ab}$ & $16 a b$ & $17.3 a$ \\
\hline $\mathrm{SC} / \mathrm{P} / \mathrm{R}$ & $8.21 a b$ & $2.22 \mathrm{ab}$ & & & $31.67 \mathrm{a}$ & $10.67 \mathrm{~b}$ & & \\
\hline $\mathrm{SL}$ & & & $6.0 \mathrm{~b}$ & $16.67 \mathrm{cbd}$ & & & $23.33 a b$ & $14.3 a$ \\
\hline $\mathrm{SL} / \mathrm{P}$ & & & $7.67 \mathrm{~b}$ & $2.22 d$ & & & 19.ab & 24.7 \\
\hline SL/P/R & & & 12.78 & $6.66 \mathrm{bcd}$ & & & $12.7 a b$ & $21 a$ \\
\hline $\mathrm{L}$ & & & $9.53 b$ & 12.67abcd & & & $28.7 a b$ & $27 a$ \\
\hline L/P & & & $16.33 b$ & $4.45 \mathrm{~cd}$ & & & $39.67 a$ & $19 a$ \\
\hline SCL/P/R & 11.49ab & $2.00 \mathrm{ab}$ & $7.17 \mathrm{~b}$ & $7 a b c d$ & $45 a$ & $40.67 a$ & $28 a b$ & $23.7 a$ \\
\hline $\mathrm{C} / \mathrm{P} / \mathrm{R}$ & 5.89ab & $6.11 \mathrm{ab}$ & & & $33.33 a$ & $16.89 \mathrm{ab}$ & & \\
\hline SC & $2.78 b$ & $7.78 \mathrm{ab}$ & & & 33.67 & $13.33 b$ & & \\
\hline $\mathrm{SC} / \mathrm{R}$ & $3.22 b$ & $00 \mathrm{~b}$ & & & 32.67 & 8.33 & & \\
\hline SC/P & $16.44 a$ & $1.44 a b$ & & & 36.33 & $1.33 b$ & & \\
\hline $\mathrm{C}$ & $1.92 b$ & $11.4 \mathrm{a}$ & & & $4.67 a$ & $12.67 \mathrm{~b}$ & & \\
\hline CL/P & 3 & $1.45 a b$ & $8 b$ & $4.99 \mathrm{~cd}$ & $42.33 a$ & $0.9 a b$ & $29.33 a b$ & $20.7 a$ \\
\hline $\mathrm{CL}$ & $6.33 a b$ & $2.22 \mathrm{ab}$ & $35.45 a$ & $3.22 d$ & 19.33 & $21.33 a b$ & $23.3 a b$ & $14.7 \mathrm{a}$ \\
\hline $\mathrm{C} / \mathrm{R}$ & 6.33ab & $3.00 \mathrm{ab}$ & & & $39.67 a$ & $12.2 b$ & & \\
\hline $\mathrm{CL} / \mathrm{R}$ & 7.33ab & $2.7 a b$ & $16.00 \mathrm{~b}$ & 9.28abcd & $15 a$ & $17 a b$ & $12 a b$ & $7.3 a$ \\
\hline CL/P/R & $6.67 a b$ & $4.83 a b$ & $14.67 \mathrm{~b}$ & $17.45 a$ & $20.0 a$ & 18.ab & $38.67 a b$ & $35.7 a$ \\
\hline SE \pm & 0.97 & 0.81 & 1.36 & 0.8 & 3.6 & 1.9 & 2.04 & 2.8 \\
\hline
\end{tabular}

Means with the same letter (s) within each column are not significantly different at 0.05 level using Duncan's Multiple Range Test. 
Agric. Biol. J. N. Am., 2011, 2(1): 109-124

Table 5 Effect of intercropping, phosphorus and inoculation on nodule weight (g) of Clitoria and lablab

\begin{tabular}{|c|c|c|c|c|c|c|c|c|}
\hline \multirow{3}{*}{ Treatment } & \multicolumn{4}{|c|}{$1^{\text {st }}$ season } & & \multicolumn{3}{|c|}{$2^{\text {nd }}$ season } \\
\hline & \multicolumn{2}{|r|}{ Clitoria } & \multicolumn{2}{|r|}{ Lablab } & \multicolumn{2}{|r|}{ Clitoria } & \multicolumn{2}{|r|}{ Lablab } \\
\hline & $6^{\text {th }}$ week & At harvest & $6^{\text {th }}$ week & At harvest & $\begin{array}{c}6^{\text {th }} \\
\text { week }\end{array}$ & At harvest & $6^{\text {th }}$ week & At harvest \\
\hline$L / P / R$ & & & $0.36 \mathrm{~b}$ & $0.89 b$ & & & $1.45 \mathrm{bc}$ & $1.53 a b$ \\
\hline $\mathrm{SCL}$ & $0.33 a$ & $0.033 b$ & $0.38 b$ & $0.22 b$ & $0.60 a$ & $1 a b$ & $1.53 \mathrm{bc}$ & $1.22 \mathrm{ab}$ \\
\hline $\mathrm{SC} / \mathrm{P} / \mathrm{R}$ & $0.113 a$ & $0.003 b$ & & & $0.40 a$ & $0.31 b$ & & \\
\hline $\mathrm{SL}$ & & & $0.15 b$ & $0.58 b$ & & & $1.33 c$ & $0.8 b$ \\
\hline SL /R & & & $0.55 b$ & $0.82 b$ & & & $1.37 \mathrm{c}$ & $1.27 a b$ \\
\hline SL/P & & & $0.46 \mathrm{~b}$ & $0.18 b$ & & & $1.87 \mathrm{bc}$ & $1 b$ \\
\hline SL/P/R & & & $1.22 b$ & $0.74 b$ & & & $1.2 \mathrm{c}$ & $1.97 a b$ \\
\hline$L$ & & & $0.67 b$ & $0.62 b$ & & & $1.73 \mathrm{bc}$ & $3.87 a$ \\
\hline$L / P$ & & & 0.71 & $0.33 b$ & & & $4.83 a$ & $1.87 a b$ \\
\hline SCL/P/R & $0.24 a$ & $0.03 b$ & $1.72 \mathrm{ab}$ & $1.06 \mathrm{~b}$ & $0.37 a$ & $1.07 a b$ & $1.9 b c$ & $2.07 a b$ \\
\hline$L / R$ & & & $1.66 a b$ & $0.84 b$ & & & $1.86 \mathrm{bc}$ & $0.4 a b$ \\
\hline SCL/R & $0.003 a$ & $0.03 b$ & $0.23 b$ & $0.44 b$ & $0.38 a$ & $0.5 b$ & $0.87 c$ & $0.67 b$ \\
\hline SCL/P & $0.03 a$ & $0.12 b$ & $0.27 b$ & $3.5 a$ & $0.70 a$ & $0.45 b$ & 1.47 & $0.77 \mathrm{~b}$ \\
\hline $\mathrm{C} / \mathrm{P}$ & $0.36 a$ & 0.033 & & & $0.67 a$ & $0.7 b$ & & \\
\hline $\mathrm{C} / \mathrm{P} / \mathrm{R}$ & 0.136 & $0.04 b$ & & & $0.47 a$ & $2.76 a$ & & \\
\hline $\mathrm{SC}$ & $0.03 a$ & $0.14 a$ & & & $0.27 a$ & $0.35 b$ & & \\
\hline SC/R & $0.02 a$ & $00 \mathrm{~b}$ & & & $0.37 a$ & 0.93 & & \\
\hline $\mathrm{SC} / \mathrm{P}$ & $0.11 a$ & 0.007 & & & $0.50 a$ & 0.32 & & \\
\hline C & $0.28 a$ & $0.60 a$ & & & $0.37 a$ & $0.38 b$ & & \\
\hline $\mathrm{CL} / \mathrm{P}$ & $0.12 a$ & 0.007 & & & 0.5 & $0.9 \mathrm{~b}$ & $2.13 b c$ & $1.55 \mathrm{ab}$ \\
\hline $\mathrm{CL}$ & $0.23 a$ & 0.37 & & & $0.14 a$ & $0.67 a b$ & $1.47 \mathrm{c}$ & $0.9 \mathrm{~b}$ \\
\hline$C / R$ & $0.15 a$ & $0.14 b$ & & & $0.30 a$ & $0.47 b$ & & \\
\hline $\mathrm{CL} / \mathrm{R}$ & $0.14 a$ & $0.04 b$ & $0.18 b$ & $0.97 b$ & $0.13 a$ & $0.7 \mathrm{~b}$ & $0.87 c$ & $1.55 a b$ \\
\hline $\mathrm{CL} / \mathrm{P} / \mathrm{R}$ & $0.24 a$ & $0.08 b$ & $0.48 b$ & $0.56 b$ & 0.2 & $0.33 b$ & $4.12 a b$ & $0.9 \mathrm{~b}$ \\
\hline $\mathrm{SE} \pm$ & 0.03 & 0.04 & 0.14 & 0.19 & 0.06 & 0.15 & 0.19 & 0.2 \\
\hline CV & 148 & 304 & 121.4 & 171.2 & 102.3 & 136.5 & 71.6 & 97.8 \\
\hline
\end{tabular}

Means with the same letter (s) within each column are not significantly different at 0.05 level using Duncan's Multiple Range Test. Legend: $\mathrm{C}=$ Clitoria, $\mathrm{L}=$ lablab, $\mathrm{S}=$ sorghum, $\mathrm{P}=$ phosphors, $\mathrm{R}=$ Rhizobium 
Agric. Biol. J. N. Am., 2011, 2(1): 109-124

Table 6 Effect of intercropping, phosphorus and inoculation on HCN (PPM) of sorghum plant

\begin{tabular}{|c|c|c|c|c|}
\hline \multirow{2}{*}{ Treatment } & \multicolumn{2}{|c|}{$1^{\text {st }}$ season } & \multicolumn{2}{|c|}{$2^{\text {nd }}$ season } \\
\hline & At $1^{\text {st }}$ harvest & $2^{\text {nd }}$ harvest & $1^{\text {st }}$ harvest & At $2^{\text {nd }}$ harvest \\
\hline \multicolumn{5}{|l|}{$L / P / R$} \\
\hline $\mathrm{SCL}$ & 157.9abc & $153.1 \mathrm{c}$ & $154.4 a$ & $159.8 a$ \\
\hline $\mathrm{SC} / \mathrm{P} / \mathrm{R}$ & $151.7 \mathrm{~b}$ & $139.5 d$ & $137.03 d$ & 136.9de \\
\hline SL & $187.02 a$ & $150.9 \mathrm{c}$ & $156.19 a$ & $153.04 \mathrm{bc}$ \\
\hline SL /R & $152 b$ & $153.3 \mathrm{c}$ & $144.5 b c$ & $153.04 a b c$ \\
\hline SL/P & $151.2 \mathrm{~b}$ & $139.4 d$ & $133.6 \mathrm{~d}$ & $134.1 \mathrm{de}$ \\
\hline SL/P/R & $135.5 b$ & $136.1 d$ & $132.5 d$ & 130.9 \\
\hline \multicolumn{5}{|l|}{ L } \\
\hline \multicolumn{5}{|l|}{ L/P } \\
\hline$S$ & 158.3ab & $160.7 \mathrm{ab}$ & $144.9 \mathrm{bcd}$ & 159.1ab \\
\hline SCL/P/R & $146.6 \mathrm{~b}$ & $138.7 d$ & $134.65 d$ & $134.4 \mathrm{de}$ \\
\hline \multicolumn{5}{|l|}{ L/R } \\
\hline SCL/R & $151.3 b$ & $155.5 \mathrm{bc}$ & $1493.4 b$ & $151.9 \mathrm{c}$ \\
\hline SCL/P & $150.3 b$ & $138.4 d$ & $134.6 \mathrm{~cd}$ & $131.9 \mathrm{de}$ \\
\hline \multicolumn{5}{|l|}{$\mathrm{C} / \mathrm{P}$} \\
\hline \multicolumn{5}{|l|}{$\mathrm{C} / \mathrm{P} / \mathrm{R}$} \\
\hline SC & 157.9ab & $156.5 \mathrm{bc}$ & 149.3ba & $156.5 \mathrm{abc}$ \\
\hline $\mathrm{SC} / \mathrm{R}$ & $155.2 b$ & $162.1 \mathrm{a}$ & $144.8 \mathrm{bc}$ & 157.9abc \\
\hline $\mathrm{SC} / \mathrm{P}$ & $133.1 \mathrm{~b}$ & $139.9 d$ & $133.2 d$ & $138.2 d$ \\
\hline $\mathrm{S} / \mathrm{P}$ & $133.3 b$ & $139.6 d$ & $132.3 d$ & $134.7 \mathrm{de}$ \\
\hline \multicolumn{5}{|l|}{$\mathrm{C}$} \\
\hline \multicolumn{5}{|l|}{$\mathrm{CL} / \mathrm{P}$} \\
\hline \multicolumn{5}{|l|}{$\mathrm{CL}$} \\
\hline \multicolumn{5}{|l|}{$\mathrm{C} / \mathrm{R}$} \\
\hline \multicolumn{5}{|l|}{$\mathrm{CL} / \mathrm{R}$} \\
\hline \multicolumn{5}{|l|}{$\mathrm{CL} / \mathrm{P} / \mathrm{R}$} \\
\hline SE \pm & 2.56 & 0.49 & 0.62 & 0.58 \\
\hline $\mathrm{CV}$ & 10.95 & 2.14 & 2.9 & 2.6 \\
\hline
\end{tabular}

Means with the same letter (s) within each column are not significantly different at 0.05 level using Duncan's Multiple Range Test. Legend: $\mathrm{C}=$ Clitoria, $\mathrm{L}=$ lablab, $\mathrm{S}=$ sorghum, $\mathrm{P}=$ phosphors, $\mathrm{R}=$ Rhizobium

\section{REFERENCES}

Abusuwar, A.O. (2005). Forage production in Sudan. $1^{\text {st }}$ ed. $U$ of K Sudan (in Arabic)

Almeida, J.P.F.; Hartwig, U.A.; Frehner, M.; Nosberger, J. and Luscher, A. (2000). Evidence that $P$ deficiency induces $N$ feedback regulation of symbiotic $\mathrm{N}_{2}$ fixation in white clover (Trifolium repen L). Journal of Experimental Botany, 51: 12891297.

British Pharmacopoeia (1980). Analytical Pharmaceutical Practical. London. Her Majesty's Stationary Office. P885.

Drevon, J.J and Hartwig, U.A (1997). Phosphorus deficiency increases the argon-induced decline of nitrogenase activity in soybean and alfalfa. Planta. 201, 463-469.

Graham, P.H. (2008). Ecological of the root-nodule bacteria of legumes. Chapter (2), p. 23-43. In Dilworth, M. J, James, E. K, Sprent, J. I and Newton, W.E. (eds.) (2008). Nitrogen-fixing Leguminous Symbioses. Nitrogen Fixation: Orgins, Application. Volume 7. Published by Sprinker. 402 pages.
Hague, L.A. and Mohamed, M.A. (1985). Phosphorus management with special references to forage legumes of Sub-Saharan Africa. Potential of forage legumes in farming system of Sub-Saharan Africa. Proceeding of workshop held at ILCA, Addis abba Ethiopia.

Herridge, D.F. (2008). Inoculation technology of legumes. Chapter (4), p 77-115. In Dilworth, M. J. James, E. K, Sprent, J.I. and Newton, W.E. (eds.) (2008). Nitrogen-fixing Leguminous Symbioses. Nitrogen Fixation: Orgins, Application. Volume 7. Published by Sprinker. 402 pages

Plaxton, W. C, Duff, S. M. G, Moorhead, G. B. G and Lefebvre. D. (1989). Phosphate starvation inducible 'bypass' of denylate and phosphate dependent glycolytic enzymes in Brassica nigra suspension cells. Plant Physiology, 90: 1275-1278.

Sa, T. M and Israel, D. W (1991). Energy status and functioning of P deficient Soybean nodules. Plant Physiology, 97:928-935.

Shambat Meteorological Station (2008). Annual report 